\title{
Vulnerability of stream biota to climate change in mediterranean- climates: a synthesis of ecological responses and conservation challenges
}

\author{
Ana Filipa Filipe ${ }^{1}$, Justin E. Lawrence ${ }^{2}$, Núria Bonada ${ }^{1}$ \\ ${ }^{1}$ Grup de Recerca "Freshwater Ecology and Management" (FEM), Departament d'Ecologia, \\ Facultat de Biologia, Universitat de Barcelona (UB), Diagonal 643, 08028 Barcelona, \\ Catalonia/Spain
}

${ }^{2}$ Department of Environmental Science, Policy \& Management, University of California, Berkeley CA 94720-3114 U.S.A.

*Correspondence: Ana Filipa Filipe, Department of Ecology, University of Barcelona, Diagonal 645, 08028 Barcelona (Catalonia), Spain. E-mail: affilipe@ub.edu. Tel: +34 934031188; fax: +34934111438.

Keywords: communities, ecological responses, freshwater species, biodiversity, mediterranean climate, distribution-range, life-history, extinction, streams 


\section{Abstract}

Freshwater species worldwide are experiencing dramatic declines partly attributable to ongoing climate change. It is expected that the future effects of climate change could be particularly severe in mediterranean-climate regions (med-regions), which host many endemic species already under great stress from the high level of human development. In this article, we review the climate and climate-induced changes in streams of med-regions and the responses of stream biota, focusing on both observed and anticipated biological responses. We also discuss current knowledge gaps and conservation challenges. Expected climate alterations have already been observed in the last decades, and include: increased annual average air temperatures; decreased annual average precipitation; hydrologic alterations; and an increase in frequency, intensity, and duration of extreme events, such as floods, droughts, and fires. Recent observations, which are concordant with forecasts built, show stream biota of med-regions when facing climate changes tend to be displaced towards higher elevations and upper latitudes, communities tend to change their composition and homogenize, while some life-history traits seem to provide biota with resilience and resistance to adapt to the new conditions (as being short -lived, small, and resistant to low streamflow and desiccation). Nevertheless, such organism's responses may be insufficient to cope with current and future environmental changes. Accurate forecasts of biotic changes and possible adaptations are difficult to obtain in med-regions mainly because of the difficulty of distinguishing disturbances due to natural variability from the effects of climate change, particularly regarding hydrology. Long-term studies are needed to disentangle such variability and improve knowledge regarding the ecological responses and detection of earlywarning signals to climate change. Investments should focus on taxa beyond fish and macroinvertebrates, and in covering the less studied regions of Chile and South Africa. 
Scientists, policy makers, and water managers must be involved in the climate change dialogue because the freshwater conservation concerns are huge.

\section{Introduction}

The apparent ongoing climate change has been attributed to human-induced alterations to the atmosphere, and is now amply considered a major threat to global freshwater biodiversity (Sala et al., 2000; Jenkins, 2003; Thuiller, 2007; Woodward et al., 2010; Maclean \& Wilson, 2011). The high rates of freshwater-biodiversity decline observed in the past decades, far greater than those measured in terrestrial ecosystems, have been mostly attributed to habitat destruction and non-native species invasions and are likely to be intensified by the effects of climate change (Vörösmarty et al., 2010).

Global circulation models project an increase in annual average air temperatures of 1$5^{\circ} \mathrm{C}$ before the end of this century (IPCC, 2007a; EEA, 2008). Trends of water temperature in streams and rivers will likely be affected, and warming is expected to occur globally, as a result of changes in climate-dependent factors, such as solar radiation and heat fluxes (Caissie, 2006; Nelson \& Palmer, 2007; Webb et al. 2008). Alterations in global precipitation patterns, both seasonal and inter-annual, are also expected, as well as increases in the intensity, duration, and/or frequency of extreme climate events, which could lead to massive floods, prolonged droughts, and intense fires (Arnell, 2004; Milly et al., 2005; Alcamo et al., 2007; EEA, 2008). The global average runoff is expected to increase because of global increase in precipitation (Goudie, 2006). Such alterations will be particularly complex in streams with significant groundwater inputs, high levels of modification, and highly variable climates (Kinouchi et al., 2007; Olden \& Naiman, 2010). Overall, climate changes are expected to have a negative impact on water resources, as the benefits of increased annual streamflow in some regions will be overwhelmed by the overall negative effects of shifts in both precipitation and streamflow regimes (IPCC, 2007b). 
Both gradual changes in climatic patterns and extreme events described above are likely to greatly affect organisms across the various stages of their life-cycles (e.g. Adrian et al., 2006; Crozier et al., 2008a; b; Blondel et al., 2010). As most aquatic organisms are ectotherms, there is a specific range of temperatures that they can tolerate for an extended time period, which determines their local and regional distribution (e.g. Burgmer et al., 2007; Haidekker \& Hering, 2007; Ohlberger et al., 2011). Additionally, most stream biota are spatially restricted to wet habitats in some life stage, and thus have limited abilities to cope with severe environmental changes, such as prolonged droughts (Bêche et al., 2009). Therefore, many stream biota may experience drastic reductions and/or changes in species distribution ranges, communities and life-histories, and ultimately undergo extinction, and some responses to such climate changes are already apparent (e.g. McCarty, 2001; Walther et al., 2002; Daufresne et al., 2003; Daufresne \& Boët, 2007; Heino et al., 2009). Both forecasts of species-distribution ranges using ecological-niche modelling and experimental studies are starting to inform climate-change science about the key environmental factors and biotic process involved, which will provide necessary knowledge for mitigation and conservation (Pearson \& Dawson, 2003). This is of critical importance because, for example, worldwide predictions suggest that up to $75 \%$ of freshwater fish biodiversity could disappear by 2070 (Xenopoulos et al., 2005).

The mediterranean-climate (hereafter referred to as med-) regions of the world are located in South-western Australia, central Chile, coastal California, Western Cape of South Africa, and around the Mediterranean Basin, and these are among the most vulnerable ecosystems to the effects of climate change (IPCC, 2007a). Having warm to hot, dry summers and mild to cool, wet winters, and being driven by large subtropical high pressure ocean cells shifting towards the poles in summer and towards the equator in winter, watercourses are characterised by predictable floods and droughts disturbance events (Gasith 
\& Resh, 1999). Climate change and consequent changes in hydrology are projected to lead to unpredictable harsh events, exacerbate water stress and desertification, and turn landscapes more desert-like (IPCC, 2007a). Such changes are expected to affect freshwater biota, despite organisms being adapted to withstand the typical natural disturbances (i.e. resistance ability) and to recover rapidly from those disturbances (i.e. resilience ability) (Grubb \& Hopkins, 1986; Lavorel et al., 1999; Bonada et al., 2007a). Simultaneously, temperate regions will become more med-like, with consequences for the occurring organisms (Lavorel et al., 1998). Nevertheless there is much current interest in investigating the impacts of climate change on biodiversity (see reviews of Parmesan, 2006 and Bellard et al., 2012), information on past and recent climate change impacts on biota inhabiting med-streams remains scattered, as well as are predictions of the ability of organisms to cope with climate change. This lack of information limits our knowledge to better address conservation and management practices for biodiversity in current freshwater med-ecosystems.

This review explores what are the observed and expected climate change effects in med-regions and inhabiting biota. We summarize studies of observed or projected impacts of climate change on such organisms, and examine organism's resilience and resistance to disturbances when facing climate change. Specifically, the aims are to: (1) describe the major environmental trends associated with climate change, (2) summarize observed and projected ecological responses of stream organisms, (3) examine the particularities of these organisms and the major conservation and management challenges, and (4) point the major key knowledge gaps.

\section{Climate change in streams of med-regions}

Med-regions are at the epicentre of some of the strongest anticipated global climate change effects (Giorgi, 2006; Baettig et al., 2007; Diffenbaugh et al., 2008). Over the past 50 years, changes in the hydrological cycle and biota in these regions have been attributed to climate 
change (e.g. Moreno \& Oechel, 1995). The Mediterranean Basin is hotter and drier, and is experiencing more extreme climatic events than it did a century ago (EEA, 2008). For example, in the Iberian Peninsula, air temperatures have unequivocally increased (De Castro et al., 2005; Trenberth et al., 2007), and aridity is more pronounced as a result of annual precipitation decreases and changes in seasonal precipitation regimes (Costa \& Soares, 2009). Climate change will induce environmental changes which will affect watercourses, as changes in hydrology, wildfire frequency and intensity, and land use,. Dramatic shifts in the hydrological patterns of fluvial ecosystems are expected, which will likely be characterized by a continued decrease in the total volume of annual runoff (rather than the increase that is expected in other climate regions) (Boix-Fayos et al., 1998). In addition, because med-region vegetation has relatively high evapotranspiration rates, decreases in streamflow will likely be more related to temperature increases than precipitation decreases (Vicuña et al., 2010).

Consequently, a higher streamflow reduction might occur than that expected if only precipitation is considered (Tague et al., 2009). In the Murray-Darling basin of Australia, for example, a $1^{\circ} \mathrm{C}$ air temperature increase results in about a $15 \%$ of basin inflow decrease (Cai \& Cowan, 2008). Regarding seasonality, expectations are for higher winter streamflows and lower summer streamflows in all med-regions (Arnell, 2004; Maurer \& Duffy, 2005; CSIRO, 2007; Souvignet et al., 2008; Adam et al., 2009; Vicuña et al., 2010). Hydrological connectivity will likely be disrupted in summer, increasing the occurrence of stream intermittency (Lake, 2003; Merelender \& Matella, this issue) and changing water quality of streams and their biota (Lindh, 1992; Avila et al., 1996; Bonada et al., 2007a). Even greater seasonal changes are anticipated for med-regions in snow-dominated basins, including parts of California, Chile, and, to a lesser extent, the Mediterranean Basin (Arnell, 1999; Adam et al., 2009; Vicuña et al., 2010). Total annual snowfall will likely be reduced and the snowmelt 
season will likely start earlier each year, which would result in higher winter streamflow than normal (Yarnell et al., 2010).

Along with seasonal changes, climate change is also likely to shift the inter-annual variability in streamflow in med-regions, i.e. the occurrence of years with extreme floods and prolonged droughts could increase, and the magnitude of the effects will depend on land-use practices. For example, filling of wetlands and channelization of streams can intensify the effects of extreme floods (Giorgi \& Lionello, 2008, Opperman et al., 2009). This inter-annual variability is likely to be more important in med-regions that are strongly subjected to ENSO, such as central Chile, where a dramatically higher rainfall period (E1 Niño) and prolonged dry period (La Niña) are forecasted in some scenarios (Mata et al., 2001).

Wildfire frequency and land uses are also expected to be affected by climate change and to affect streams (IPCC, 2007a). However, those changes are relatively more difficult to forecast because they are also driven, to a relatively high extent, by social and economic circumstances, such as the availability of fire-fighting services (e.g. Pausas, 2004). Models forecast a pronounced increase in frequency and intensity of wildfires because the drought period may be elongated (Moriondo et al., 2006; Anav \& Mariotti, 2011). Projected effects of land-use changes on ecosystems are not encouraging, as strong impacts on the biota and on the ecosystem services provisions are expected (Lambin et al., 2003).

Lastly, the described climate or climate-induced changes are expected to shift medregions towards more desert-like landscapes (Lavorel et al., 1998). Some expansion of medclimate areas is also forecasted, although with regional differences. For example, expansions are expected in the Mediterranean Basin and the Chilean med-regions, whereas contractions are expected in the South African and Australian med-regions (Klausmeyer \& Shaw, 2009). 


\section{Responses of freshwater biota to climate change in med-regions}

Climate and climate-induced changes can alter severely the suitability of med-stream local habitats because of higher temperatures, lack of oxygen, streamflow reduction and/or disruptions in connectivity, and stream biota certainly will be impacted by such changes (e.g. Magoulick \& Kobza, 2003; Magalhães et al., 2007; Crozier el al., 2008b; Filipe et al, 2010). Of the studies conducted on climate change and biota reported by the ISI Web of Knowledge from 1899 to 2011 , those focusing on freshwaters are scarce (7.7\% of all studies) and only $0.4 \%$ of all studies focus on med-streams. The number of studies published annually on climate change and biota have been increasing tremendously since 1990 (Figure 1a), and a similar trend was observed for publications regarding climate change effects on streams (Figure 1b), and among those the ones focused on med-regions (Figure 1c). Such increasing interest in stream biodiversity of med-regions allowed us to summarize the observed or predicted stream biota responses to climate and climate-induced changes, namely in shifts in their distribution and communities, adaption through plasticity in phenology, or extinction (Visser, 2008; Table 1; Figure 2).

\section{Distribution range shifts}

Some species may shift their distributional ranges to keep up with climate change based on their dispersal abilities and physiological tolerances to the new and favourable hosting habitats (Hoffman \& Parsons, 1997). Observations as well as prediction based on nichemodelling techniques point to distributional shifts for biota as a response to climate change (Parmesan, 2006). Such forecasts, available for some common species, have been obtained primarily from niche-based, species-distribution models (SDMs; Pearson \& Dawson, 2003), and using temperature and precipitation scenarios (McCarty, 2001).

The observed or predicted distributional shifts for med-stream biota indicate displacements mostly upward and poleward (Otero et al., 2011; Table 1). For example, a few 
African Odonata species now have been recorded in the southern Europe, which has been attributed to climate change (Romero, 1981; Betoret, 2000, Rodríguez, 2011). Forecasts indicate cold-water fish species with physiological optima $<20^{\circ} \mathrm{C}$ (e.g. Salmo trutta) will probably undergo habitat losses leading to strong reductions in their range (Filipe et al., 2012). In contrast, cool-water species with physiological optima $20-28{ }^{\circ} \mathrm{C}$ and warm-water species with physiological optima $>28^{\circ} \mathrm{C}$ (e.g. genera Barbus and Leuciscus) are predicted to colonize newly suitable areas in higher-elevation reaches or extend their range poleward (Buisson \& Grenouillet, 2009; Buisson et al., 2010; Lassalle \& Rochard, 2009). A similar pattern is expected for Plecoptera species based on known autoecological data, and only a few species with wider thermal tolerance ranges and drought resistance ability are expected to expand their distribution ranges and population sizes (Tierno de Figueroa et al., 2010).

There is great opportunity to further improve forecasts regarding distributional shifts of biota. Most studies are probably overpredicting biota occurrence in the future because dispersal abilities and hindrance to pathways of dispersion, such as anthropogenic barriers (e.g. dams, culverts, and weirs) and orographic barriers (e.g. river basin limits) are not usually being considered (Magalhães et al., 2002; Filipe et al., 2009). Forecasts can be improved by also considering the abilities and barriers for displacement of non-native organisms, which are a great concern in freshwaters (Rahel \& Olden, 2008) and this has been addressed in a few med-regions (e.g. Gritti et al., 2006 for plants; Vila-Gispert et al., 2005 for fish). Additionally, the detailed knowledge of the relationship between species and environmental variability obtained from observations collected in either nature or in the laboratory can provide more realistic results (e.g. Yates et al., 2010). For example, water temperature in nature can have different effects on the overwinter survival of aquatic organisms of distinct age-classes, and such differences can be incorporated (e.g. McCarthy et al., 1999). Finally, 
the inclusion of multiple environmental drivers of change into forecasts can enhance the reliability of their predictions, namely hydrological and land use factors (Sala et al., 2000).

\section{Community changes}

Species range shifts can lead to changes in species richness, turnover, and community reassembly (i.e. changes in taxonomic composition of assemblages). Assessments of changes in community structure attributed to climate change have been often based on long-term observations, whereas forecasts are, to date, less common (Parmesan \& Yohe, 2003).

Regarding med-streams, Feio et al. (2010) observed in a 15-year study of macroinvertebrate assemblages that climate variability and associated hydrological variation can lead to great changes in taxonomic composition. Also, in California, Bêche \& Resh (2007a;b) showed that temporal variability of taxonomic composition tends to be greater than trait-composition variability. Prolonged droughts may have greater effects on biota than short droughts, including the provision of favourable conditions for invasion or biotic exchange (Table 1). In particular, Bêche et al. (2009) observed lack of resilience and resistance during a 5-year, prolonged drought in California med-streams. Strong changes were observed primarily in the composition of macroinvertebrate assemblages and an invasive fish species (Lepomis cyanellus) became established. Also, native fish abundance tends to be lowest during drought years and highest during wet years (Magalhães et al., 2007), and is further affected by human water demands (Slaughter \& Wiener, 2007).

Forecasts built for freshwater fish assemblages suggest that future communities will depend on position along the upstream-downstream gradient. For example, midstream assemblages located mostly at medium elevations are likely to undergo major shifts, including increases in species richness and species reassembly resulting from both the arrival of non native species and local extinctions (Buisson et al., 2008, 2010). However, predictive studies focused on assemblages are generally very limited for biota of med-streams. 


\section{Life-history traits}

Changes of life-history traits in organisms, including phenological changes (i.e. shifts of seasonal activity driven by environmental factors) have been observed as ecological effects of recent climate change, with similar trends for terrestrial, marine, and freshwater groups (Parmesan, 2006). Regarding streams and rivers in med-regions, recent long-term data attributed changes in life-history traits of benthic algae, macroinvertebrates, and fish to climate and climate-induced changes, such as reduced streamflow and droughts (Table 1). Only a few studies exist, however, and they are restricted to three of the five med-regions (i.e. California, Mediterranean Basin, and Australia).

The advance of spring reproduction events, which is one of the most documented effects of climate change on terrestrial fauna, has been observed for some aquatic macroinvertebrate taxa. For example, incremental changes in temperature were identified as the main cause of changes observed in the life cycle of a mayfly (Ephoron virgo) in the Iberian Peninsula, including shifts in secondary production, sex ratio, larval development, and adult emergence (Cid et al., 2008). Large and long-lived organisms with high food electivity tend to decrease in abundance as a result of hydrology changes related to dryness, while organisms with desiccation-resistant eggs and strong dispersal abilities (as by flight or stream drift) tend to be more abundant because they resist and recover better from extreme droughts and are less dependent of drought refuges, such as deep pools (e.g., Magalhães et al., 2007; Table 1). In fact, macroinvertebrates of med-streams tend to have shorter generation times (less than a year to complete their life-cycle), which facilitates survival and the overcoming of local extinctions (Bonada et al., 2007a), and small, short-lived organisms may benefit from higher temperatures because of their fast metabolism (Daufresne et al., 2009, Lawrence et al., 2010). 
Other evidences come from studies on how species react to thermal and hydrological variability (Power et al., 2008). Temperature variability can affect blooms of phytoplankton and zooplankton (e.g. Winder \& Schindler, 2004), the growth, timing of development and emergence of macroinvertebrates (e.g. Bayoh \& Lindsay, 2003), and migration of fish in freshwaters (e.g. Matthews, 1998). Also, high mobility and small body size facilitates organisms rapid response and recovery from large variations in streamflow (Bonada et al., 2007b; Pires et al., 2010; Chester \& Robson, 2011).

Opportunities exists for future research at the intersection of environmental variability associated with climate change and life-history characteristics, including whether: 1) a threshold in trait responses can result from genetic-variance constraints; 2) contrasting effects of environmental changes, such as extreme hydrological events, enhance biota matches or mismatches with the environment; and 3) there are consequences on population dynamics (Stenseth \& Mysterud, 2002; Stenseth et al., 2002). For example, for brown trout (Salmo trutta), which is a cold-water fish, local adaptations to a range of temperatures have been observed, and some populations may have the potential to adapt to changing temperature regimes because of their genetic variance and phenotypic plasticity (Jensen et al., 2008).

\section{Extinctions}

To our knowledge, no record of extinction of species in med-stream inhabitants has been attributed entirely to climate change. However, several species that were widespread in the past now are now very rare and are thus more vulnerable to extinction (e.g. the caddisflies Chimarra marginata: Bonada et al., 2007a; Ch. lusitanicum: Rogado et al., 2005; or Annitella sp. C. Zamora-Muñoz pers. com.). Most likely, we are not aware of the existing species risk in med-regions, mainly because not all of the risks are known, and the taxonomy of most freshwater groups is far from complete (Bonada et al., 2008a; Davies, this issue; De Moor \& Day, this issue; Tierno de Figueroa et al., this issue). 
The expected rapid loss of suitable habitats makes it probable that next extinctions will occur for geographically restricted species, which are common in the highly endemic med-regions. High, mountain streams are especially vulnerable to extinctions and it has been predicted that biota in mountainous areas of med-regions will be particularly affected (Zamora-Muñoz et al., 2008; Tierno de Figueroa et al., 2010; Filipe et al., 2012). Also, headwaters tend to have a high $ß$-diversity accounting a large degree of regional biodiversity at both population, genetic and community levels (Finn et al., 2011). In fact, the first record of a species extinction attributed to climate change was a highly restricted freshwater species, the golden toad (Bufo periglenes) inhabiting the tropical forest mountains in Costa Rica (Pounds et al., 2005, 1999; Pounds \& Crump, 1994).

\section{Conservation concerns related to climate change in med-regions}

\section{Unique and highly threatened biota}

Some observations suggest that biota inhabiting med-streams might be more vulnerable to taxonomic extinction triggered by climate change and climate-induced changes than biota inhabiting streams in more stable climate regions.

First, med-regions typically have a high level of endemism and freshwater taxonomic diversity relative to other climate regions (Gasith \& Resh, 1999; Bonada et al., 2007a). For example, the Mediterranean Basin hosts many endemic species and is considered one of the most important hotspots of freshwater biodiversity (Bianco, 1995; Filipe et al., 2009; Hermoso et al., 2009; Hermoso et al., 2011; Tierno de Figueroa et al., this issue). The medregion of California is also considered a biodiversity hotspot and the amount of recent urbanization in this region is a serious conservation concern (Davis et al., 2007). Med-regions in South Africa, South America, and Australia are also recognized as global centres of endemism and taxonomic diversity, and are home to many rare and endangered fish and 
amphibian species (Van Rensburg et al., 1999; Fitzpatrick et al., 2008; Heads, 2009). In the Chilean med-region, $81 \%$ of the known fish species are endemic and $40 \%$ are endangered (Habit et al., 2006). Additionally, the regional taxa richness tend to be higher in med-streams than in streams of temperate climate regions while local taxa richness may not significantly differ between both climate regions (Bonada et al., 2007a), and med-streams tend to have lower local abundances than streams in temperate regions (e.g. Magalhães et al., 2002, Statzner et al., 2007a; Bonada et al., 2007a). Altogether these biodiversity patterns of medstreams may lead to a high biodiversity loss driven environmental changes. Second, in spite of being highly resistant and resilient to natural harsh environments, these biota will likely be vulnerable to the projected hydrological extreme events that severely alter habitats (though less vulnerable to temperature increases because the resident biota are mostly eurithermic). Throughout evolutionary history organism's resistance and resilience abilities to relatively predictable extreme events that occurred in the past in a very heterogeneous environment allowed the persistence med-stream biota in these biodiversity hotspots. But organism's responses to the already ongoing climate change will depend on the intensity, frequency, and duration of future extreme events, which are expected to be considerably distinct, and such responses will likely vary from the individual to the community level (Rundel, 1998). Third, the empty species niches that will be open through extinction and displacement of species most likely will be occupied by non-native species (Smith \& Darwall, 2006, Statzner et al., 2007b, Rahel \& Olden, 2008). The establishment of non-native species (Clavero \& GarcíaBerthou, 2006) is already considered a primary driver of change in med-regions, together with climate change, both with expected profound effects on the community composition, distribution, phenology, and physiological acclimation of species (Parmesan, 2006; see also Ficke et al., 2007). Finally, med-streams are already under a great deal of human stress with many species threatened, and climate-change effects in these landscapes could be exacerbated 
in the future as water demands increase (IPCC, 2007b). Such demands could impact ecosystems and biodiversity in such a magnitude that surpasses the intrinsic resistance and resilience capabilities of biota.

In resume, species from med-streams already highly threatened are likely to be more vulnerable to extinction than eurithermic species of temperate streams, with large distribution ranges and inhabit more stable environments.

\section{Conservation investments}

In med-streams the taxonomic and functional biodiversity of aquatic biota is declining rapidly despite legal tools in place for their protection, leaning to an increase of species endangerment (Table 2). As climate change might favour species that are more tolerant to higher water temperatures and pollution, or to water withdrawals (Gasith, 1991; Davies et al., 1993; Sabater et al., 1995; Gasith \& Resh, 1999; Lawrence et al., 2011), biological invasions of non-native species are expected to occur more frequently, and biotic communities will tend to be more homogenised and with fewer endemic species (Clavero \& García-Berthou, 2006). Such alterations in communities will lead to poorer stream 'ecological status', as defined in current management programs worldwide, such as the Water Framework Directive or the Clean Water Act (Moyle, 1995; Munné \& Prat, 2010; see Table 2 for details).

The described ongoing environmental problems in med-streams are expected to be exacerbated by the human responses to climate change, including increased surface-water withdrawals, inter-basin diversions, and groundwater abstractions for agricultural, industrial, and municipal uses (Gleick \& Palaniappan, 2010). As a consequence, fisheries in particular will probably continue to suffer diminishing returns, which compromise the capacities of developed countries to maintain strong economies and of developing countries to meet food demands (Worm et al., 2009). Proactive management strategies that reduce environmental stressors beyond climate change, including pollution, overharvesting, water withdrawals, 
water diversions, habitat destruction, and introductions of non-native species, are necessary to sustain freshwater ecosystems in the future (Ficke et al., 2007).

It is apparent that legal policies in the med-regions are not providing or ensuring adequate conservation of freshwater biodiversity (Johnson et al., 2001). In California, for example, legal frameworks completely ignore climate-change impacts, and none adequately addresses freshwaters (Viers \& Rheinheimer, 2011). However, one of the methods already being implemented that address, at least partially, the freshwater conservation aims is the establishment of regional environmental streamflow standards. Such methods allocate water of appropriate quality to ecosystems with a magnitude, frequency, duration, timing, and rate of change that is as similar as possible to the natural flow regime, while simultaneously meeting the water needs for the various human uses of water (Acreman \& Dunbar, 2004; Arthington et al., 2006, Poff et al., 2010). Nevertheless, the implementation of freshwaterprotected areas is still far from assuring the maintenance of freshwater biodiversity (Saunders et al., 2002; Filipe et al., 2004; Hermoso et al., 2009). Societal changes focused on good practices of water-use could also benefit protection and management of freshwater biodiversity in med-regions (Wolff et al., 1989; Gasith \& Resh, 1999; Fleckenstein et al., 2004).

Many developed countries already included in their budgets a specific allocation for climate-change mitigation. For example, the 2011 budget of the United States of America included US \$171.3 million ( $€ 128.3$ million) for the Climate Change Adaptation Initiative, an increase of almost five times higher than the 2010 budget (Department of the Interior, 2011). For the European Union, estimations of climate change total costs was around $€ 60$ billion (US $\$ 81$ billion) per year, reaching three times more for the high-cost scenarios (Behrens et al., 2008). Particularly in Europe, efforts are underway and funds are allocated to address the effects of climate change in streams, including med-streams (see WISER project 
$<$ http://www.wiser.eu $>$ and EURO-LIMPACS $<$ http://www.refresh.ucl.ac.uk/eurolimpacs $>$ ), and a particular concern has been how to evaluate and forecast future water quality under the aims of the EU Water Framework Directive. However, calculating costs and benefits of climate-change policies involves immense complexity and uncertainty, and probably not enough efforts are being made to address such unique and threatened biodiversity as the one inhabiting med-streams (Behrens et al., 2008).

\section{Research needs related to climate change in med-regions}

\section{Long-term data collection}

Most of the studies described herein were conducted in med-streams of California, Mediterranean Basin and Australia, in restricted local areas, focusing on fish and/or macroinvertebrates, and using data collections from relatively short time-series (Maximum 30-y; Otero et al., 2011, though most were much shorter). Therefore, to our knowledge, overall there are few species records available that can be used to explicitly determine the effects of climate change (Table 1). To address this data shortage, the collection of long-term ecological data should be made both a national and an international funding priority among med-regions and across various taxa so that ecological responses can be measured in such high-risk regions (Resh et al., this issue). Studies using long-term data to assess spatial and temporal variability of stream communities, and the resilience and resistance of the members of these communities to natural and anthropogenic disturbances, will allow biotic responses to climate change to be examined at different scales. Forecasts from habitat-niche models (SDMs) can also be improved by using long-term data.

\section{Ecological response to disturbance}

Organisms might not be able to adapt and respond by their resilience and resistance abilities to the new disturbance regimes resulting from climate change that surpass the intensity, 
frequency, or duration thresholds of natural disturbances (Lytle, 2007; Lytle et al., 2008). The ability of biota to cope with these disturbances is very poorly understood, which weakens the predictive accuracy of the ecological responses. Additionally, the difficulty of disentangling ecological responses resulting from either anthropogenic or natural disturbances characterized by predictable inter- and intra-annual climatic and hydrologic oscillations also weakens advances in knowledge (Gasith \& Resh, 1999; Lake, 2000; Humphries \& Baldwin, 2003). For example, studies focused on the effects of droughts on biota in med-streams often fail to classify the drying period as a seasonal highly predictive event or climate change induced event because long-term data is rarely available (but see references in Table 1).

Scenarios of future extreme events are just in the early stage of development (Tebaldi et al., 2006) and will be critical to assessing the potential impacts of climate change in medstreams, as well as including other anthropogenic disturbances (e.g. evaluating effects of climate change in disturbed sites).

\section{Genetic diversity}

Genetic diversity, which is frequently not considered in studies of climate-change effects, is of major relevance when examining the potential ecological impacts of climate change, and forecasts based on taxonomy only might be omitting an important component of biodiversity. Often cryptic, the intraspecific patterns of genetic diversity have been recorded for medstreams (e.g. Lopes-Cunha et al., 2012), and should be considered when quantifying climatechange effects because it might be lost as a result of range contractions (Bálint et al., 2011) and it can potentiate the ability of species to adapt to new environments (Visser, 2008). In particular, phylogenetic constraints and conservation of ancient life-history traits might limit or impede ecological responses, which enforce the necessity of considering evolutionary aspects to advance knowledge regarding life-history traits (Bonada et al., 2008b). 
Some recent work conducted outside of the med-regions (i.e. in England) examined microevolution using field experiments to simulate conditions of altered climate (Van Doorslaer et al., 2010). These authors examined the genetic adaptations to increasing temperature in life-history traits of the water flea (Daphnia), and found changes in size at maturity. If sufficient genetic variation was present, such adaptations occured within a single growing season. However, to our knowledge, such microevolutionary responses have not been examined for biota inhabiting med-streams. Microevolution rates can clearly be determinant for ecological responses to environmental changes, together with species interactions across tropic levels (Jenouvrier \& Visser, 2011; Van der Putten et al., 2010).

\section{Conclusions}

Climate change effects in med-regions have already been reported (e.g. EEA, 2008; Pausas, 2004), while clear documented responses of organisms to climate change in med-streams are still scarce, notwithstanding these regions are considered an important biodiversity hotspot worldwide (Myers et al., 2000; Malcolm et al., 2006; IUCN, 2008). Here we conclude that responses of organisms inhabiting med-streams to climate change are/or will be mostly driven by changes in hydrology, including changes in the intensity, duration, and frequency of disturbance events (Table 1). Land-use future changes probably will not be such a strong driver as for terrestrial organisms, and will be probably surpassed by climate and biotic changes (Sala et al., 2000).

Responses observed or predicted for freshwater organisms to climate and climate induced-changes span an array of organizational hierarchy, from species to communities, as for terrestrial and marine organisms (Parmesan, 2006). Where favourable and accessible habitats exist, cool-water and warm-water species in med-streams will likely colonize new habitats at higher altitudes or latitudes and become established, whereas cold-water species will probably undergo local extinctions and reductions in their range as a result of habitat loss 
(Table 1). However, geographic displacements to more favourable habitats may be compromised if suitable habitats are inexistent nearby or inaccessible because oceanic or other barriers as distinct environments (e.g., deserts) (e.g. in South Africa, Chile and Australia) or anthropogenic barriers (e.g., dams and reservoirs), common across med-regions (Lehner et al., 2011). Additionally, some taxa inhabiting med-streams may be able to cope with local environmental changes because of their life-history traits, such as shorter generation times, and small body size, or colonize new habitats because of their high dispersal ability (Bonada et al., 2007a; Daufresne et al., 2009, Lawrence et al., 2010). In fact, the life-history traits may allow med-stream biota to adapt to the natural patterns of hydrological extreme events typical of these regions, and, under certain thresholds of disturbance, may even confer resistance and resilience that would allow them to survive under climate change. Finally, rapid genetic adaptations of traits may occur under selection pressures (Van Doorslaer et al., 2010), but the role of such adaptations for biota inhabiting med-streams is not widely understood.

Despite the array of likely responses of stream biota to climate changes in medregions, arguments support that such biota are more prone to extinction triggered by climate change than biota inhabiting streams at more stable climate regions. Although med-stream biota have traits acquired through evolution in a predictable climate regarding droughts and floods frequency, the high endemism, species rarity, and low local abundance, together with the already and growing biotic homogenisation and other strong divers of change, make this biodiversity at high risk under climate change. Ecological effects of climate change rest on the question of whether species and communities inhabiting med-streams will be able to adapt fast enough to keep up with their changing environment or whether the rapidity and severity of climate change will exceed their ability to respond (Parmesan, 2006). 
We are only at an early stage in projecting accurately future trends of biota, and the current strong bias on taxonomic group examined and geographic regions covered delays advances of such predictions. Very few studies focus on Chile and South Africa med-regions or in other taxa beyond fish and macroinvertebrates, leaving a large component of freshwater biodiversity of med-streams unrepresented. Also, when compared with streams in more stable climate regions, inter- and intra-annual natural variability in med-streams is a relatively large confounding factor regarding climate change impacts (Gasith \& Resh, 1999). It is thus imperative to collect and manage long-term data for distinct med-regions and across taxonomic groups to provide confidence in the accuracy and extrapolation of climate change predictions. Also, although faunal convergence was reported for med-regions (e.g., Bonada et al., 2008b; Blondel et al., 2010), there are distinct taxa evolutionary histories that cannot be disregarded when inferring likely organism's responses to climate change among analogous med-regions .

New challenges are evident concerning management and conservation of med-regions because organisms will respond to the interaction of all future changes that come on top of a range of unique environmental and socioeconomic problems already present, such as desertification, water scarcity, pollution, and food-production limitations (Balanza et al., 2007; Iglesias et al., 2007; Hill et al., 2008; Underwood et al., 2009). The urgency of planning and acting is intensified by the anticipated rates of warming greater than the global average (Cayan et al., 2006; Christensen et al., 2007; IPCC, 2007a; Giorgi \& Lionello, 2008; Giannakopoulos et al., 2009). Integration of ecological predictions in an economic context will support conservation and management options and prioritizing investments, as it is vital to determine where to invest and what actions to take (see for South Africa Wintle et al. 2011). 
In conclusion, a better knowledge of how freshwater biota will respond to climate change requires increased investments in data gathering, monitoring, and model-building forecasts. At this point, few data exist for most taxa present in med-streams, and many of them are already considered endangered. Such advances in biodiversity knowledge and projections of future trends, together with changes in management and societal attitudes will be the best way to deal with the growing challenges of freshwater conservation in medregions. Conservation and management challenges will require huge efforts by multiple stakeholders to advance scientific knowledge and implement new practices.

\section{Acknowledgments}

Current research was supported by the BioFresh EU project- Biodiversity of Freshwater Ecosystems: Status, Trends, Pressures, and Conservation Priorities (7th FWP contract No 226874) and the United States National Science Foundation (NSF) Engineering Research Center (ERC) for Re-inventing the Nation's Urban Water Infrastructure (ReNUWIt).

\section{References}

Acreman, M. \& M. J. Dunbar, 2004. Defining environmental flow requirements - a review. Hydrology and Earth Sciences 8: 861-876.

Adam, J. C., A. F. Hamlet \& D. P. Lettenmaier, 2009. Implications of global climate change for snowmelt hydrology in the twenty-first century. Hydrological Processes 23: 962972.

Adrian, R., S. Wilhelm \& D. Gerten, 2006. Life-history traits of lake plankton species may govern their phenological response to climate warming. Global Change Biology 12: $652-661$. 
Alcamo, J, M. Flörke \& M. Marker, 2007. Future long-term changes in global water resources driven by socio- economic and climatic change. Hydrological Sciences 52: $247-275$

Anav, A. \& A. Mariotti, 2011. Sensitivity of natural vegetation to climate change in the EuroMediterranean area. Climate Research 46: 277-292.

Aparicio, E., M. J. Vargas, J. M. Olmo \& A. de Sostoa, 2000. Decline of native freshwater fishes in a mediterranean watershed on the Iberian Peninsula: a quantitative assessment. Environmental Biology of Fishes 59: 11-19.

Arnell, N. W., 1999. Climate change and global water resources. Global Environmental Change 9: S31-S49.

Arnell, N. W., 2004. Climate change and global water resources: SRES emissions and socioeconomic scenarios. Global Environmental Change 14: 31-52.

Arthington, A. H., S. E. Bunn, N. L, Poff \& N. J. Naiman, 2006. The challenge of providing environmental flow rules to sustain river ecosystems. Ecological Applications 16: $1311-1318$.

Avila, A., C. Neal \& J. Terradas, 1996. Climate change and implications for streamflow and streamwater chemistry in a mediterranean catchment. Journal of Hydrology 177: 99116.

Baettig, M B, M. Wild \& D. M. Imboden, 2007. A climate change index: Where climate change may be most prominent in the 21 st century. Geophysical Research Letters 34 : L01705.

Balanza, R., P. García-Lorda, C. Pérez-Rodrigo, J. Aranceta, M. B. Bonet \& J. Salas-Salvado, 2007. Trends in food availability by the Food and Agriculture Organization's food balance sheets in Mediterranean Europe in comparison with other European areas. Public Health Nutrition 10: 168-176. 
Bálint, M. S., Domisch, C. H. M. Engelhardt, P. Haase, S. Lehrian, J. Sauer, K. Theissinger, S. U. Pauls \& C. Nowak, 2011. Cryptic biodiversity loss linked to global climate change. Nature Climate Change 1: 313-318.

Bayoh, M. N. \& S. W. Lindsay, 2003. Effect of temperature on the development of the aquatic stages of Anopheles gambiae sensu stricto (Diptera: Culicidae). Bulletin of Entomological Research 93: 375-381.

Bêche, L. A. \& V. H. Resh, 2007a. Biological traits of benthic macroinvertebrates in California mediterranean-climate streams: long-term annual variability and trait diversity patterns. Fundamental and Applied Limnology 169: 1-23.

Bêche, L. A. \& V. H. Resh, 2007b. Short-term climatic trends affect the temporal variability of macroinvertebrates in California 'mediterranean' streams. Freshwater Biology 52: $2317-2339$.

Bêche, L. A., P. G. Connors, V. H. Resh \& A. M. Merenlender, 2009. Resilience of fishes and invertebrates to prolonged drought in two California streams. Ecography 32: 778788.

Behrens, A., J. N. Ferrer \& C. Egenhofer, 2008. Financial Impacts of Climate Change: Implications for the EU Budget. Centre for European Policy Studies, CEPS Working Document No. 300. [available on internet at http://www.ceps.eu].

Bellard, C., C. Bertelsmeier, P. Leadley, W. Thuiller \& F. Courchamp, 2012. Impacts of climate change on the future of biodiversity. Ecology Letters 15: 365-377.

Betoret, B., 2000. Expansion de Trithemis annulata en Europa en los años 80 y 90 (Odonata). Boletín Sociedad Entomológica Aragonesa 27: 85-86.

Bianco, P. G., 1995. Mediterranean endemic freshwater fishes of Italy. Biological Conservation 72: 159-170. 
Blondel, J., J. Aronson, J.-Y. Bodiou \& G. Boeuf, 2010. The Mediterranean Region: Biological Diversity Through Time And Space. Oxford University Press, Oxford.

Boix-Fayos, C., A. Calvo-Cases, A. C. Imeson, M. D. Soriano Soto \& I. R. Tiemessen, 1998. Spatial and short-term temporal variations in runoff, soil aggregation and other soil properties along a mediterranean climatological gradient. Catena, 33: 123-138.

Bonada, N., S. Dolédec \& B. Statzner, 2007a. Taxonomic and biological trait differences of stream macroinvertebrate communities between mediterranean and temperate regions: implications for future climatic scenarios. Global Change Biology 13: 1658-1671.

Bonada, N., M. Rieradevall \& N. Prat, 2007b. Macroinvertebrate community structure and biological traits related to flow permanence in a mediterranean river network. Hydrobiologia 589: 91-106.

Bonada, N., M. Rieradevall, H. Dallas, J. Davies, J. Day, R. Figueroa, V. H. Resh, V.H. \& N. Prat, 2008b. Multi-scale assessment of macroinvertebrate richness and composition in mediterranean-climate rivers. Freshwater Biology 53: 772-788

Bonada, N., C. Zamora-Muñoz, M. El Alami, C. Múrria \& N. Prat, 2008a. New records of Trichoptera in reference mediterranean-climate rivers of the Iberian Peninsula and north of Africa: taxonomical, faunistical and ecological aspects. Graellsia, 64: 189-208.

Buisson, L. \& G. Grenouillet, 2009. Contrasted impacts of climate change on stream fish assemblages along an environmental gradient. Diversity and Distributions 15: 613-626.

Buisson, L., L. Blanc \& G. Grenouillet, 2008. Modelling stream fish species distribution in a river network: the relative effects of temperature versus physical factors. Ecology of Freshwater Fish 17: 244-257.

Buisson, L, G. Grenouillet, N. Casajus \& S. Lek, 2010. Predicting the potential impacts of climate change on stream fish assemblages. American Fisheries Society Symposium 73: 327-346. 
Burgmer, T., H. Hillebrand \& M. Pfenninger, 2007. Effects of climate-driven temperature changes on the diversity of freshwater macroinvertebrates. Oecologia 151: 93-103.

Cai, W. \& T. Cowan, 2008. Evidence of impacts from rising temperature on inflows to the Murray-Darling Basin. Geophysical Research Letters 35: L07701.

Caissie, D., 2006. The thermal regime of rivers: a review. Freshwater Biology 51: 13891406.

Cayan, D. R., E. P. Maurer, M. D. Dettinger, M. Tyree, K. Hayhoe, 2006. Climate change scenarios for the California region. Climatic Change 87: S21-S42.

Cid, N., C. Ibáñez \& N. Prat, 2008. Life history and production of the burrowing mayfly Ephoron virgo (Olivier, 1791) (Ephemeroptera: Polymitarcyidae) in the lower Ebro river: a comparison after 18 years. Aquatic Insects 30: 163- 178.

Chester, E. T. \& B. J. Robson, 2011. Drought refuges, spatial scale and recolonisation by invertebrates in non-perennial streams. Freshwater Biology 56: 2094-2104.

Christensen, J. H., B. Hewitson, A. Busuioc, A. Chen, X. Gao, R. Held, R. Jones, R. K. Kolli, W. K. Kwon, R. Laprise, V. Magana Rueda, L. Mearns, C. G. Menendez, J. Räisänen, A. Rinke, A. Sarr, P. Whetton, R. Arritt, R. Benestad, M. Beniston, D. Bromwich, D. Caya, J. Comiso, R. de Elia \& K Dethloff, 2007. Regional climate projections. In Solomon, S., D. Qin, M. Manning, Z. Chen, M. Marquis, K. Averyt, M. Tignor \& H. Miller (eds), Climate Change 2007: The Physical Science Basis. Contribution of working group I to the fourth assessment report of the intergovernmental panel on climate change. Cambridge University Press, Cambridge: 847-940.

Clavero, M. \& E. García-Berthou, 2006. Homogenization dynamics and introduction routes of invasive freshwater fish in the Iberian Peninsula. Ecological Applications 16: 23132324. 
Costa, A. C. \& A. Soares, 2009. Trends in extreme precipitation indices derived from a daily rainfall database for the South of Portugal. International Journal of Climatology 29: 1956-1975.

Crozier, L. G., A. P. Hendry, P. W. Lawson, T. P. Quinn, N. J. Mantua, J. Battin, R. G. Shaw \& R. B. Huey, 2008a. Potential responses to climate change in organisms with complex life histories: evolution and plasticity in Pacific salmon. Evolutionary Applications 1: $252-270$.

Crozier, L. G., R. W. Zabel \& A. F. Hamlet, 2008b. Predicting differential effects of climate change at the population level with life-cycle models of spring Chinook salmon. Global Change Biology 14: 236-249.

CSIRO, Australian Bureau of Meteorology, 2007. Climate Change in Australia: Technical Report. CSIRO and the Bureau of Meteorology, Australia. [available on internet at http://climatechangeinaustralia.com.au].

Daufresne, M., M. C. Roger, H. Capra \& N. Lamouroux, 2003. Long-term changes within the invertebrate and fish. communities of the Upper Rhône River: effects of climatic factors. Global Change Biology 10: 124-140.

Daufresne, M. \& P. Boët, 2007. Climate change impacts on structure and diversity of fish communities in rivers. Global Change Biology 13: 2467-2478.

Daufresne, M., K. Lengfellner \& U. Sommer, 2009. Global warming benefits the small in aquatic ecosystems. Proceedings of the National Academy of Sciences of the United States of America 106: 12788-12793.

Davies, this issue

Davies, B. R., J. H. O'Keeffe \& C. D. Snaddon, 1993. A Synthesis of the Ecological Functioning, Conservation and Management of South African River Ecosystems. Report No. TT 62/93. Water Research Commission, Pretoria. 
Davis, E. B., M.S. Koo, C. Conroy, J. L. Patton \& C. Moritz, 2007. The California Hotspots Project: identifying regions of rapid diversification of mammals. Molecular Ecology 17: $120-138$.

De Castro, M., J. Martín-Vide \& S. Alonso, 2005. The climate of Spain: past, present and scenarios for the 21st century. In J. M. Moreno (eds), A Preliminary General Assessment of the Impacts in Spain due to the Effects of Climate Change. Spanish Ministry of Environment, Madrid: 1-62.

De Moor \& Day, this issue

Department of the Interior, 2011. Climate change adaptation. 2011 Budget of the United States of America. [available on internet at http://www.doi.gov/budget/2011/11Hilites/toc.html].

Diffenbaugh, N. S., F. Giorgi \& J. S. Pal, 2008. Climate change hotspots in the United States, Geophysical Research Letters 35: L16709.

EEA, European Environment Agency, 2008. Impacts of Europe's Changing Climate - 2008 Indicator-based Assessment. EEA-JRC-WHO report. EEA, Copenhagen.

Feio, M. J., N. C. Coimbra, M. A. S. Graça, S. J. Nichols \& R. H. Norris. 2010. The influence of extreme climatic events and human disturbance on macroinvertebrate community patterns of a mediterranean stream, over $15 \mathrm{y}$. Journal of the North American Benthological Society 29: 1397-1409.

Ficke, A. D., C. A. Myrick \& L. J. Hansen, 2007. Potential impacts of global change on freshwater fisheries. Reviews in Fish Biology and Fisheries 17: 581-613.

Filipe, A. F., M. B, Araújo, I. Doadrio \& P. L. Angermeier \& M. J.Collares-Pereira, 2009. Biogeography of Iberian freshwater fishes revisited: the roles of historical versus contemporary constraints. Journal of Biogeography 36: 2096-2110. 
Filipe, A. F., M. F. Magalhães \& M. J. Collares-Pereira, 2010. Native and introduced fish species richness in mediterranean streams: the role of multiple landscape influences. Diversity and Distributions 16: 773-785.

Filipe, A. F., Markovic, D., Pletterbauer, F., Tisseuil, C., De Wever, A.; Schmutz, S., Bonada, N., J. Freyhof, 2012. The ability to forecast fish distribution along stream networks: brown trout (Salmo trutta) in Europe. Diversity and Distributions.

Filipe, A. F., T. Marques, S. G. Seabra, P. Tiago, F. Ribeiro, L. Moreira da Costa, I. G. Cowx \& M. J. Collares-Pereira, 2004. Selection of priority areas for fish conservation in the Guadiana River Basin, Iberian Peninsula. Conservation Biology 18: 189-200.

Finn, D. S., N. Bonada, C. Múrria \& J. M. Hughes, 2011. Small but mighty: headwaters are vital to stream network biodiversity at two levels of organization. Journal of North American Benthological Society 30: 963-980.

Fitzpatrick, M. C., A. D. Gove, N. J. Sanders \& R. R. Dunn, 2008. Climate change, plant migration, and range collapse in a global biodiversity hotspot: the Banksia (Proteaceae) of Western Australia. Global Change Biology 14: 1337-1352.

Fleckenstein, J., M. Anderson, G. Fogg \& J. Mount, 2004. Managing surface watergroundwater to restore fall flows in the Cosumnes River. Journal of Water Resources Planning and Management 130: 301-310.

Gaigher, I. G., K. C. D. Hamman \& S. C. Thorne. 1980. The distribution, conservation status and factors affecting the survival of indigenous freshwater fishes in the Cape Province. Koedoe 23: 57-58.

Gasith, A., 1991. Conservation and management of the coastal streams of Israel: an assessment of stream status and prospect for rehabilitation In Boon, P., G. Petts \& P. Calow (eds), River Conservation and Management. John Wiley \& Sons, New York: 5163. 
Gasith, A. \& V. H. Resh, 1999. Streams in mediterranean climate regions: abiotic influences and biotic responses to predictable seasonal events. Annual Review of Ecology and Systematics 30: 51-81.

Giannakopoulos, C., P. Le Sager, M. Bindi, M. Moriondo, E. Kostopoulou \& C.M. Goodess, 2009. Climatic changes and associated impacts in the Mediterranean resulting from a $2^{\circ} \mathrm{C}$ global warming. Global and Planetary Change 68: 209-224.

Giorgi, F., 2006. Climate change hot-spots. Geophysical Research Letters 33: L08707.

Giorgi, F. \& P. Lionello, 2008. Climate change projections for the Mediterranean region. Global and Planetary Change 63: 90-104.

Gleick, P. H. \& M. Palaniappan, 2010. Peak water limits to freshwater withdrawal and use. Proceedings of the National Academy of Sciences of the United States of America 107: $11155-11162$.

Goudie, A. S., 2006. Global warming and fluvial geomorphology. Geomorphology 79: 384394.

Gritti, E. S., B. Smith \& M. T. Sykes, 2006. Vulnerability of Mediterranean Basin ecosystems to climate change and invasion by exotic plant species. Journal of Biogeography 33: 145-157.

Grubb, P. J. \& A.J. M. Hopkins, 1986. Resilience at the level of the plant community. In B. Dell, A. J. M. Hopkins \& B. B. Lamont, Resilience in Mediterranean-type Ecosystems: Dr W Junk Publishers, Dordrecht: 1-38.

Habit, E., D. Brian \& I. Vila, 2006. Current state of knowledge of freshwater fishes of Chile. Gayana 70: 100-113

Haidekker, A. \& D. Hering, 2007. Relationship between benthic insects (Ephemeroptera, Plecoptera, Coleoptera, Trichoptera) and temperature in small and medium-sized streams in Germany: a multivariate study. Aquatic Ecology 42: 463-481. 
Heads, M., 2009. Globally basal centres of endemism: the Tasman-Coral Sea region (southwest Pacific), Latin America and Madagascar/South Africa. Biological Journal of the Linnean Society 96: 222-245.

Heino, J., R. Virkkala \& H. Toivonen, 2009. Climate change and freshwater biodiversity: detected patterns, future trends and adaptations in northern regions. Biological Reviews 84: 39-54.

Hermoso, V., S. Linke \& J. Prenda, 2009. Identifying priority sites for the conservation of freshwater fish biodiversity in a mediterranean basin with a high degree of threatened endemics. Hydrobiologia 623: 127-140.

Hermoso, V., S. Linke, J. Prenda \& H. P. Possingham, 2011. Addressing longitudinal connectivity in the systematic conservation planning of fresh waters. Freshwater Biology 56: 57-70.

Hill, J., M. Stellmes, T. Udelhoven, A. Röder \& S. Sommer, 2008. Mediterranean desertification and land degradation: Mapping related land use change syndromes based on satellite observations. Global and Planetary Change 64: 146-157.

Hoffman, A. A. \& P. A. Parsons, 1997. Extreme Environmental Change and Evolution Cambridge University Press, Cambridge.

Humphries, P. \& D. Baldwin, 2003. Drought and aquatic ecosystems: an introduction. Freshwater Biology 48: 1141-1146.

Iglesias, A., L. Garrote, F. Flores \& M. Moneo, 2007. Challenges to manage to risk of water scarcity and climate change in the Mediterranean. Water Resources Management 21: 775-788.

IPCC (Intergovernmental Panel on Climate Change), 2007a. Climate change 2007: the physical science basis. Contribution of Working Group I to the Fourth Assessment 
Report of the IPCC. Cambridge University Press, Cambridge. [available on internet at http://www.ipcc.ch]

IPCC (Intergovernmental Panel on Climate Change), 2007b. Climate change 2007: impacts, adaptation, and vulnerability. Contribution of Working Group II to the Fourth Assessment Report of the IPCC. Cambridge University Press, Cambridge. [available on internet at http://www.ipcc.ch]

IUCN, International Union for Conservation of Nature, 2008. IUCN Red List of Threatened Species. IUCN, Gland and Cambridge. [available on internet at http://www.iucnredlist.org]

Jenkins, M., 2003. Prospects for biodiversity. Science 302: 1175-1177.

Jennings, M. R. \& M. P. Hayes, 1994. Amphibians and Reptile Species of Special Concern in California. California Department of Fish and Game, Sacramento.

Jenouvrier, S. \& M. E. Visser, 2011. Climate change, phenological shifts, eco-evolutionary responses and population viability: toward a unifying predictive approach. International Journal of Biometeorology 55: 905-919.

Jensen, L. F., M. M. Hansen, C. Pertoldi, G F. Holdensgaard, K.-L. Dons, 2008. Local adaptation in brown trout early life-history traits: implications for climate change adaptability. Proceedings of the Royal Society B 275: 2859-2868

Johnson, N., C. Revenga \& J. Echeverria, 2001. Managing water for people and nature. Science 292: 1071-1072.

Kinouchi, T., H. Yagi \& M. Miyamoto, 2007. Increase in stream temperature related to anthropogenic heat input from urban wastewater. Journal of Hydrology 335: 78-88.

Klausmeyer, K. R. \& M. R. Shaw, 2009. Climate change, habitat loss, protected areas and the climate adaptation potential of species in Mediterraenan ecosystems worldwide. PLoS ONE 4: 1-9. 
Knapp, R. A. \& K. R. Matthews, 2000. Non-native fish introductions and the decline of the mountain yellow-legged frog from within protected areas. Conservation Biology 14: $428-438$.

Lake, P. S., 2000. Disturbance, patchiness, and diversity in streams. Journal of the North American Benthological Society 19: 573-592.

Lake, P. S., 2003. Ecological effects of perturbation by drought in flowing waters. Freshwater Biology 48: 1161-1172.

Lambin, E. F., H, J. Geist \& E. Lepers, 2003. Dynamics of land-use and land-cover change in tropical regions. Annual Review of Environment and Resources 28: 205-241.

Lassalle, G. \& E. Rochard, 2009. Impact of twenty-first century climate change on diadromous fish spread over Europe, North Africa and the Middle East. Global Change Biology 15: 1072-1089.

Lavorel, S., B. Touzard, J. D. Lebreton \& B. Clément, 1998. Identifying functional groups for response to disturbance in an abandoned pasture. Acta Oecologica 19: 227-240.

Lavorel, S., S. McIntyre \& K. Grigulis 1999. Plant response to disturbance in a mediterranean grassland: How many functional groups? Journal of Vegetation Science 10: 661-672.

Lawrence, J. E., M. J. Deitch \& V. H. Resh, 2011. Effects of vineyard coverage and extent on benthic macroinvertebrates in mediterranean-climate streams of Northern California. Annales de Limnologie. International Journal of Limnology 47: 347-354.

Lawrence, J. E., K. E. Lunde, R. D. Mazor, L. A. Bêche, E. P. McElravy \& V. H. Resh, 2010. Long-term macroinvertebrate response to climate change: implications for biological assessment in mediterranean-climate streams. Journal of the North American Benthological Society 29: 1424-1440. 
Lehner, B., C.R. Liermann, C. Revenga, et al., 2011. High-resolution mapping of the world's reservoirs and dams for sustainable river-flow management. Frontiers in Ecology and the Environment 9: 494-502.

Lindh, G., 1992. Hydrological and water resources impact of climate change. In Jeftic, L., J.D. Milliman \& G. Sestini (eds), Climatic Change and the Mediterranean:

Environmental and Societal Impacts of Climatic Changes and Sea-Level Rise in the Mediterranean Region. Edward Arnold, London: 58-93.

Lopes-Cunha, M., M. A. Aboim, N. Mesquita, M. J. Alves, I. Doadrio \& M. M. Coelho, 2012. Population genetic structure in the Iberian cyprinid fish Iberochondrostoma lemmingii (Steindachner, 1866): disentangling species fragmentation and colonization processes. Biological Journal of the Linnean Society 105: 559-572.

López-Rodriguez, M. J., J. M. Tierno de Figueroa \& J. Alba-Tercedor, 2009. The life history of Serratella ignita (Poda, 1761) (Insecta: Ephemeroptera) in a temporary and permanent mediterranean stream. Aquatic Sciences 71: 179-188.

Lymbery, A. J., M. Hassan., D. L. Morgan, S. J. Beatty \& R. G. Doupé, 2010. Parasites of native and exotic freshwater fishes in south-western Australia Journal of Fish Biology 76: $1770-1785$.

Lytle, D. A., 2007. Life-history and behavoural daptations to flow regime in aquatic insects. Aquatic insects - challenges to populations. In Lancaster J. \& R. A. Briers (eds), Proceedings of the Royal Entomological Society's 24th symposium. Preston, UK.

Lytle, D. A., M. T. Bogan \& D. S. Finn, 2008. Evolution of aquatic insect behaviours across a gradient of disturbance predictability. Proceedings of the Royal Society B 22: 453462. 
Maclean, I. M. D. \& R. J. Wilson, 2011. Recent ecological responses to climate change support predictions of high extinction risk. Proceedings of the National Academy of Sciences of the United States of America 108: 12337-12342.

Magalhães, M. F., Batalha, D. C. \& M. J. Collares-Pereira, 2002. Gradients in stream fish assemblages across a mediterranean landscape: contributions of environmental factors and spatial structure. Freshwater Biology 47: 1015-1031.

Magalhães, M. F., Beja, P. \& I. J. Schlosser, 2007. Effects of multi-year droughts on fish assemblages of seasonally drying mediterranean streams. Freshwater Biology 52: 14941510.

Magoulick, D. D. \& R.M. Kobza, 2003. The role of refugia for fishes during drought: a review and synthesis. Freshwater Biology 48: 1186-1198.

Malcolm, J. R., C. Liu, R. P. Neilson, L. Hansen \& L. Hannah, 2006. Global warming and extinctions of endemic species from biodiversity hotspots. Conservation Biology 20: 538-548.

Mas-Martí, E., E. García-Berthou, S. Sabater, S. Tomanova, I. Muñoz, 2010. Comparing fish assemblages and trophic ecology of permanent and intermittent reaches in a mediterranean stream. Hydrobiologia 667: 167-180.

Mata, L. J., M. Campos, E. Basso, R. Compagnucci, P. Fearnside, A. Magrin, J. Marengo, A. R. Moreno, J Suárez, S. Solman, A. Villamizar\& L. Villers, 2001. Latin America. In IPCC, Intergovernmental Panel on Climate Change (eds), Climate change 2001: impacts, adaptation, and vulnerability. Contribution of working group II to the third assessment report of the Intergovernmental Panel on Climate Change. Cambridge University Press, Cambridge: 693-734.

Matthews W. J., 1998. Patterns in freshwater fish ecology. Chapman \& Hall, New York. 
Maurer, E. P. \& P. B. Duffy, 2005. Uncertainty in projections of streamflow changes due to climate change in California. Geophysical Research Letters 32: L03704.

Mazor, R., A. Purcell \& V. H. Resh, 2009. Long-term variability in benthic macroinvertebrate bioassessments: A 20-year study from two northern Californian streams. Environmental Management 43: 1269-1286.

McCarty, J.P., 2001. Ecological consequences of recent climate change. Conservation Biology, 15: 320-331.

McCarthy, I. D., Moksness, E., Pavlov, D. A. \& D. F. Houlihan, 1999 Effects of water temperature on protein synthesis and protein growth in juvenile Atlantic wolffish (Anarhichas lupus). Canadian Journal of Fisheries and Aquatic Sciences 56: 231-241.

Merelender \& Matella, this issue

Milly, P. C. D., K. A. Dunne \& A.V. Vecchia, 2005. Global pattern of trends in stream flow and water availability in a changing climate. Nature 438: 347-350.

Moreno, J. M. \& W. C. Oechel, 1995. Global change and Mediterranean-type Ecosystems. Springer, New York.

Moriondo, M., P. Good, R. Durao, M. Bindi, C. Gianakopoulos \& J. Corte-Real, 2006. Potential impact of climate change on fire risk in the Mediterranean area. Climate Research 31: 85-95.

Moyle, P. B., 1995. Conservation of native freshwater fishes in the mediterranean-type climate of California, USA: A review. Biological Conservation 72: 271-279.

Munné, A. \& N. Prat, 2011. Effects of mediterranean climate annual variability on stream biological quality assessment using macroinvertebrate communities. Ecological Indicators 11: 651-662.

Myers, N., R. A. Mittermeier, C. G. Mittermeier, G. A. B. Da Fonseca \& J. Kent, 2000. Biodiversity hotspots for conservation priorities. Nature 403: 853-858. 
Nelson, K. C. \& M. A. Palmer, 2007. Stream temperature surges under urbanization and climate change: Data models, models, and responses. Journal of the American Water Resources Association 43: 440-452.

Nicola, G. G., A. Almodóvar, B. Elvira, 2009. Influence of hydrologic attributes on brown trout recruitment in low-latitude range margins. Oeologia 160: 515-524.

Ohlberger, J., E. Edeline, L. A. Vollestad, N. C. Stenseth \& D. Claessen, 2011. Temperaturedriven regime shifts in the dynamics of size-structured populations. The American Naturalist 177: 211-223.

Olden, J. D. \& R. J. Naiman, 2010. Incorporating thermal regimes into environmental flows assessments: modifying dam operations to restore freshwater ecosystem integrity. Freshwater Biology 55: 86-107.

Opperman, J. J., G. E. Galloway, J. Fargione, J. F. Mount, B. D. Richter \& S. Secchi, 2009. Sustainable floodplains through large-scale reconnection to rivers. Science 326: 14871488.

Otero, I, M. Boada, A. Badiab, E. Plac, J. Vayredac, S. Sabaté, C. A. Gracia J. Peñuelas, 2011. Loss of water availability and stream biodiversity under land abandonment and climate change in a mediterranean catchment (Olzinelles, NE Spain). Land Use Policy 28: $207-218$.

Parmesan, C., 2006 Ecological and evolutionary responses to recent climate change. Annual Review of Ecology, Evolution, and Systematics 37: 637-636.

Parmesan, C. \& G. Yohe, 2003. A globally coherent fingerprint of climate change impacts across natural systems. Nature 421: 37-42.

Pausas, J. G., 2004. Changes in fire and climate in the eastern Iberian Peninsula (Mediterranean Basin). Climatic Change 63: 337-350. 
Pearson, R. G. \& T. P. Dawson, 2003. Predicting the impacts of climate change on the distribution of species: are bioclimate envelope models useful? Global Ecology and Biogeography 12: 361-371.

Pires, D. F., A. M. Pires, M. J. Collares-Pereira \& M. F. Magalhães, 2010. Variation in fish assemblages across dry-season pools in a mediterranean stream: effects of pool morphology, physicochemical factors and spatial context. Ecology of Freshwater Fish: 19: 74-86.

Poff, N. L., B. D. Richter, A. H. Arthington, S. E. Bunn, R. J. Naiman, E. Kendy, M. Acreman, C. Apse, B. P. Bledsoe, M. C. Freeman, J. Henriksen, R. B. Jacobson, J. G. Kennen, D. M. Merritt, J. H. O’Keeffe, J. D. Olden, K. Rogers, R. E. Tharme \& A. Warner, 2010. The ecological limits of hydrologic alteration (ELOHA): a new framework for developing regional environmental flow standards. Freshwater Biology 55: 147-170.

Pounds, J. A. \& M. L. Crump, 1994 Amphibian declines and climate disturbance: the case of the golden toad and the harlequin frog. Conservation Biology 8: 72-85.

Pounds, J. A., M. P. L. Fogden \& J. H. Campbell, 1999. Biological response to climate change on a tropical mountain. Nature 398: 611-15.

Pounds, J. A., M. P. L. Fogden \& K. L. Masters, 2005. Case study: responses of natural communities to climate change in a highland forest. In T. E. Lovejoy \& L. Hannah (eds), Climate change and biodiversity. Yale University Press, London: 70-74.

Power, M. E., M. S. Parker \& W. E. Dietrich, 2008. Seasonal reassembly of a river food web: floods, droughts, and impacts of fish. Ecological Monographs 78: 263-282.

Rahel, F. J. \& J. D. Olden, 2008. Assessing the effects of climate change on aquatic invasive species. Conservation Biology 22: 521-533. 
Resh, V. H., L. Bêche, J. E. Lawrence, R. Mazor, E. P. McElravy, A. P. O'Dowd \& S. Carlson, this issue. Long-term population and community patterns of benthic macroinvertebrates and fishes in northern California mediterranean-climate streams. Hydrobiologia.

Robson, B. J., E. T. Chester \& C. M. Austin, 2011. Why life history information matters: drought refuges and macroinvertebrate persistence in non-perennial streams subject to a drier climate. Marine and Freshwater Research 62: 801-810

Robson, B. J., T. G. Matthews, P.R. Lind, N.A. Thomas. 2008. Pathways for algal recolonization in seasonally-flowing streams. Freshwater Biology 53: 2385-2401. Rogado, L., P.J. Alexandrino, P.R. Almeida, M.J. Alves, J. Bochechas, R.V. Cortes, M.I. Domingos, A.F. Filipe, J. Madeira \& M.F. Magalhães, 2005. Peixes dulciaquícolas e migradores. In Cabral, M. J., J. Almeida, P. R. Almeida, T. Dellinger, N. Ferrand de Almeida, M. E. Oliveira, J. M. Palmeirim, A. I. Queirós, L. Rogado \& M. Santos-Reis (eds), Livro Vermelho dos Vertebrados de Portugal. Instituto da Conservação da Natureza, Lisboa: 63-114.

Rodríguez, J. M., 2011. Trithemis kirbyi ardens (Gerstaecker, 1891) (Odonata: Libellulidae): datos de campo sobre su ecología en el Sur de España y primeros registros para la provincia de Sevilla (España). Métodos en Ecología y Sistemática 6: 10.

Romero, M. F., 1981. Un odonato nuevo para la fauna Ibérica, Trithemis annulata (Palisot de Bemvais, 1805) (Anisoptera,Libellulidae). Boletín Asociación Española de Entomología4: 191-193.

Rundel, P. W., 1998. Landscape disturbance in mediterranean-type ecosystems: an overview. In Rundel P. W., Montenegro G. \& Jaksic F. M. (eds), Landscape Disturbance and Biodiversity in Mediterranean-Type Ecosystems. Ecological Studies 136. SpringerVerlag, Berlin: 3-22. 
Sabater, F., H. Guash, E. Martí \& J. Armengol, 1995. The River Ter: a mediterranean river case study in Spain. Ecosystems of the World 22: 419.

Sala, O. E., F. S. Chapin, J. J. Armesto, et al., 2000. Global biodiversity scenarios for the year 2100. Science 287: 1770-1774.

Saunders, D. L., J. J. Meeuwig \& A. C. J. Vincent, 2002. Freshwater protected areas: Strategies for Conservation. Conservation Biology 16: 30-41.

Skelton, P. H., J. A. Cambray, A. Lombard \& G. A. Benn, 1995. Patterns of distribution and conservation status of freshwater fishes in South Africa. South African Journal of Zoology 30: 71-81.

Slaughter, R. A. \& J. D. Wiener, 2007. Water, adaptation, and property rights on the Snake and Klamath Rivers. Journal of the American Water Resources Association 43: 308321.

Smith, K. G. \& W. R. T. Darwall, 2006. The Status and Distribution of Freshwater Fish Endemic in the Mediterranean Basin. IUCN, International Union for Conservation of Nature, Glandand and Cambridge.

Soto, D., I. Arismendi, J. González, J. Sanzana, F. Jara, C. Jara, E. Guzmán \& A. Lara, 2006. Southern Chile, trout and salmon country: invasion patterns and threats for native species. Revista Chilena de Historia Natural 79: 97-117.

Statzner, B., N. Bonada \& S. Dolédec 2007a. Conservation of taxonomic and biological trait diversity of European stream macroinvertebrate communities: a case for a collective public database. Biodiversity and Conservation 16: 3609-3632.

Statzner B., Bonada N. \& S. Dolédec, 2007b. Biological attributes discriminating invasive from native European stream macroinvertebrates Biological Invasions 10: 517-530. 
Stenseth N. C. \& A. Mysterud, 2002. Climate, changing phenology, and other life history traits: Nonlinearity and match-mismatch to the environment. Proceedings of the National Academy of Sciences of the United States of America 99: 13379-13381.

Stenseth N. C. \& A. Mysterud, G. Ottersen, J. W. Hurrell, K-S Chan, M. Lima, 2002. Ecological Effects of Climate Fluctuations. Science 297: 1292-1296.

Souvignet, M., H. Gaese, L. Ribbe, N. Kretschmer \& R. Oyarzun, 2008 Climate Change Impacts on Water Availability in the Arid Elqui Valley, North Central Chile: a Preliminary Assessment. IWRA, International Water Resources Association, World Water Congress, Montpellier.

Tague, C., L. Seaby \& A. Hope, 2009. Modelling the eco-hydrologic response of a mediterranean type ecosystem to the combined impacts of projected climate change and altered fire frequencies. Climatic Change 93: 137-135.

Tebaldi, C., Hayhoe, K., Arblaster, J. M. \& G. A. Meehl, 2006. Going to the extremes: An intercomparison of model-simulated historical and future changes in extreme events. Climatic Change 79: 185-211.

Tierno de Figueroa et al., this issue Tierno de Figueroa, J. M., M. J. López-Rodríguez, A. Lorenz, W. Graf, A. Schmidt-Kloiber \& D. Hering, 2010. Vulnerable taxa of European Plecoptera (Insecta) in the context of climate change. Biodiversity and Conservation 19: 1269-1277.

Thuiller, W., 2007. Biodiversity - climate change and the ecologist. Nature 448: 550-552.

Trenberth, K.E. \& S. A. Josey, 2007. Observations: surface and atmospheric climate change. In In Solomon, S., D. Qin, M. Manning, Z. Chen, M. Marquis, K. B. Averyt, M. Tignor \& H. L. Miller (eds), Climate Change 2007: The Physical Science Basis. Contribution of Working Group I to The Fourth Assessment Report of The Intergovernmental Panel On Climate Change. Cambridge University Press, Cambridge: 235-336. 
Underwood, EC, J. H. Viers, K.R. Klausmeyer, R. L. Cox \& M. Shaw, 2009. Threats and biodiversity in the mediterranean biome. Diversity and Distributions 15: 188-197.

Van der Putten, W. H., M. Macel, E. V. Vissel, 2010. Predicting species distribution and abundance responses to climate change: why it is essential to include biotic interactions across trophic levels. Philosophical Transactions of the Royal Society of London Series B 365: 2025-2034.

Van Doorslaer, W., R. Stoks, I. Swillen, H. Feuchtmayr, D. Atkinson, B. Moss \& L. De Meester, 2010. Experimental thermal microevolution in community-embedded Daphnia populations. Climate Research 43: 81-89.

Van Rensburg, B. J., M. A. McGeoch, S. L. Chown \& A. S. Van Jaarsveld, 1999. Conservation of heterogeneity among dung beetles in the Maputaland Centre of Endemism, South Africa. Biological Conservation 88: 145-153.

Vicuña, S., R. D. Garreaud \& J. Mcphee, 2010. Climate change impacts on the hydrology of a snowmelt driven basin in semiarid Chile. Climatic Change 105: 469-488.

Viers, J. H. \& D. E. Rheinheimer, 2011. Freshwater conservation options for a changing climate in California's Sierra Nevada. Marine and Freshwater Research 62: 266-278.

Vila-Gispert, A., C. Alcaraz \& E. Garcia-Berthou, 2005. Life-history traits of invasive fish in small mediterranean streams. Biological Invasions 7: 107-116.

Visser, M. E., 2008. Keeping up with a warming world; assessing the rate of adaptation to climate change. Proceedings of the Royal Society B 275: 649-659.

Vörösmarty, C. J., McIntyre, P. B., Gessner, M. O., Dudgeon, D., Prusevich, A., Green, P., Glidden, S., Bunn, S. E., Sullivan C. A., Reidy Liermannm, C. \& P. M. Davies, 2010. Global threats to human water security and river biodiversity. Nature 467: 555-561. 
Walther, G. R., E. Post, P. Convery, A. Menzel, C. Parmesan, T. J. Beebee, J. M. Fromentin, O. Hoegh-Guldberg \& F Bairlein, 2002. Ecological responses to recent climate change. Nature 416: 389-395.

Webb, B. W., D. M. Hannah, R. Dan Moore, L. E. Brown \& F. Nobilis, 2008. Recent advances in stream and river temperature research. Hydrological Processes 22: 902918.

Winder, M. \& D. E. Schindler, 2004. Climate change uncouples trophic interactions in an aquatic ecosystem. Ecology 85: 2100-2106.

Wintle, B. A., S. A. Bekessy, D. A. Keith, B. W. van Wilgen, M. Cabeza, B. Schröder, S. B. Carvalho, A. Falcucci, L. Maiorano, T. J. Regan, C. Rondinini, L. Boitani \& H. P. Possingham, 2011. Ecological-economic optimization of biodiversity conservation under climate change. Nature Climate Change 1: 355-359.

Wolff, S. W., T. A. Wesche \& W. Hubert, 1989. Stream channel and habitat changes due to flow augmentation. Regulated Rivers and Management 4: 225-233.

Woodward, G., D. M. Perkins \& L. E. Brown, 2010. Climate change and freshwater ecosystems: Impacts across multiple levels of organization. Philosophical Transactions of the Royal Society of London B 365: 2093-2106.

Worm, B., R. Hilborn, J. K. Baum, T. A. Branch, et al., 2009. Rebuilding Global Fisheries. Science 325: 578-585.

Xenopoulos, M. A., D. M. Lodge, J. Alcamo, M. Märker, K. Schulze \& D. P. Van Vuuren, 2005. Scenarios of freshwater fish extinctions from climate change and water withdrawal. Global Change Biology 11: 1557-1564.

Yarnell, S. M., J. H. Viers \& J. F. Mount, 2010. Ecology and management of the spring snowmelt recession. BioScience 60: 114-127. 
Yates, C. J., J. Elith, A. M. Latimer, D. L.Maitre, G. F. Midgely, F. M. Shurr \& A. G. West, 2010. Projecting climate change impacts on species distributions in megadiverse South African Cape and Southwest Australian Floristic Regions: Opportunities and challenges. Austral Ecology 35: 374-391.

Zamora-Muñoz, C., A. Sánchez-Ortega, J. Alba-Tercedor, 2008. Physico-chemical factors that determine the distribution of mayflies and stoneflies in a high-mountain stream in Southern Europe (Sierra Nevada, Southern Spain). Aquatic Insects 15: 11-20. 


\section{Tables and Figures}

Table 1. Observed and forecasted changes in biodiversity related with climate change (or

climate-induced) on freshwater organisms in streams of mediterranean climate regions (med-

regions). Studies were listed according to a literature search at Web of Science. MedBasin

refers to Mediterranean Basin region.

\begin{tabular}{|c|c|c|c|c|c|c|}
\hline $\begin{array}{l}\text { Biodiversity } \\
\text { Changes }\end{array}$ & $\begin{array}{l}\text { Med- } \\
\text { region }\end{array}$ & $\begin{array}{l}\text { Time } \\
\text { period }\end{array}$ & Taxa & Observations or Predictions & $\begin{array}{l}\text { Correlated } \\
\text { drivers }\end{array}$ & Source \\
\hline \multirow[t]{7}{*}{ Distribution } & $\begin{array}{l}\text { MedBasin } \\
\text { (South- } \\
\text { western } \\
\text { Spain) }\end{array}$ & 1980 & $\begin{array}{l}\text { Trithemis } \\
\text { annulata } \\
\text { (Odonata) }\end{array}$ & $\begin{array}{l}\text { Species expanded distribution } \\
\text { range to South of Spain from } \\
\text { Africa; also previously } \\
\text { detected in Italia, Sicilia and } \\
\text { Sardena }\end{array}$ & $\begin{array}{l}\text { Climate } \\
\text { (hotter and } \\
\text { dryer } \\
\text { summers) }\end{array}$ & $\begin{array}{l}\text { Romero } \\
\text { et al } \\
(1981)\end{array}$ \\
\hline & $\begin{array}{l}\text { MedBasin } \\
\text { (Southern } \\
\text { Europe) }\end{array}$ & $\begin{array}{l}1980 \mathrm{~s}- \\
1990 \mathrm{~s}\end{array}$ & $\begin{array}{l}\text { Trithemis } \\
\text { annulata } \\
\text { (Odonata) }\end{array}$ & $\begin{array}{l}\text { Species expanded distribution } \\
\text { range to Spain, Italy, and } \\
\text { Greece from Africa. Also } \\
\text { evidences of similar expansion } \\
\text { for Mesogomphus genel, } \\
\text { Hemiax ephippiger, and } \\
\text { Diplacodes lefebvrei } \\
\end{array}$ & $\begin{array}{l}\text { Climate } \\
\text { (hotter and } \\
\text { dryer } \\
\text { summers) }\end{array}$ & $\begin{array}{l}\text { Betoret } \\
(2000)\end{array}$ \\
\hline & $\begin{array}{l}\text { MedBasin } \\
\text { (Southwest } \\
\text { ern Spain) }\end{array}$ & $\begin{array}{l}2010- \\
2011\end{array}$ & $\begin{array}{l}\text { Trithemis } \\
\text { kirbyi } \\
\text { (Odonata) }\end{array}$ & $\begin{array}{l}\text { Species expanded distribution } \\
\text { range to South of Spain from } \\
\text { Africa }\end{array}$ & $\begin{array}{l}\text { Climate } \\
\text { (hotter and } \\
\text { dryer } \\
\text { summers) }\end{array}$ & $\begin{array}{l}\text { Rodrígue } \\
\text { z et al } \\
(2011)\end{array}$ \\
\hline & $\begin{array}{l}\text { MedBasin } \\
\text { (North- } \\
\text { eastern } \\
\text { Spain) } \\
\end{array}$ & $\begin{array}{l}1991- \\
20180 \mathrm{~s}\end{array}$ & $\begin{array}{l}\text { Salmo trutta } \\
\text { (fish) }\end{array}$ & $\begin{array}{l}\text { Species in future decades will } \\
\text { disappear in lowland habitats, } \\
\text { and occupy upstream reaches } \\
\text { at higher altitudes }\end{array}$ & $\begin{array}{l}\text { Warming and } \\
\text { change in } \\
\text { precipitation } \\
\text { regime }\end{array}$ & $\begin{array}{l}\text { Filipe et } \\
\text { al. (2011) }\end{array}$ \\
\hline & $\begin{array}{l}\text { MedBasin } \\
\text { (South- } \\
\text { eastern } \\
\text { France) }\end{array}$ & $\begin{array}{l}2051- \\
2080 \mathrm{~s}\end{array}$ & Fishes & $\begin{array}{l}\text { Species distributional ranges } \\
\text { in future decades will diminish } \\
\text { for cold-water species (located } \\
\text { in headwaters), while cool- } \\
\text { water and warm-water species } \\
\text { will expand to suitable habitats } \\
\text { upstream }\end{array}$ & $\begin{array}{l}\text { Warming and } \\
\text { change in } \\
\text { precipitation } \\
\text { regime }\end{array}$ & $\begin{array}{l}\text { Buisson } \\
\text { et al. } \\
(2008 \text {, } \\
2010)\end{array}$ \\
\hline & $\begin{array}{l}\text { MedBasin } \\
\text { (Europe, } \\
\text { North } \\
\text { Africa and } \\
\text { the Middle } \\
\text { East) }\end{array}$ & $\begin{array}{l}2070- \\
2080 \mathrm{~s}\end{array}$ & $\begin{array}{l}\text { Fishes } \\
\text { (diadromous) }\end{array}$ & $\begin{array}{l}\text { Species distribution ranges } \\
\text { across large river basins in } \\
\text { future decades will: contract } \\
\text { (14 species will lose suitable } \\
\text { basins), have little or no } \\
\text { changes (five species), or } \\
\text { expand (three species } \\
\text { colonizing northward) }\end{array}$ & Climate & $\begin{array}{l}\text { Lassalle } \\
\& \\
\text { Rochard } \\
(2009)\end{array}$ \\
\hline & $\begin{array}{l}\text { MedBasin } \\
\text { (North- } \\
\text { eastern } \\
\text { Spain) }\end{array}$ & $\begin{array}{l}1978- \\
2008\end{array}$ & $\begin{array}{l}\text { Macroinvertebr } \\
\text { ates, fishes, } \\
\text { mammals }\end{array}$ & $\begin{array}{l}\text { Disappeared white-clawed } \\
\text { crayfish (Austropotamobius } \\
\text { pallipes), Mediterranean } \\
\text { barbell (Barbus meridionalis), } \\
\text { chub (Squalius cephalus), } \\
\text { European eel (Anguilla } \\
\text { anguilla), and water vole } \\
\text { (Arvicola sapidus) }\end{array}$ & $\begin{array}{l}\text { Warming, } \\
\text { decrease } \\
\text { runoff-rainfall } \\
\text { ratio }(15 \% \\
\text { lower than } 30 \\
\text { years ago })\end{array}$ & $\begin{array}{l}\text { Otero et } \\
\text { al. }(2011)\end{array}$ \\
\hline
\end{tabular}




\begin{tabular}{|c|c|c|c|c|c|c|}
\hline \multirow[t]{8}{*}{ Community } & $\begin{array}{l}\text { California } \\
\text { (Northern) }\end{array}$ & $\begin{array}{l}1984- \\
2002\end{array}$ & $\begin{array}{l}\text { Invertebrates, } \\
\text { fishes }\end{array}$ & $\begin{array}{l}\text { Organisms impacted } \\
\text { negatively and had no } \\
\text { resilience during drought. } \\
\text { Assemblage composition of } \\
\text { invertebrates did not recover } \\
\text { while richness and abundance } \\
\text { recovered quickly. Native fish } \\
\text { abundance was lowest during } \\
\text { drought and invasive fish } \\
\text { species established and was } \\
\text { resilient to subsequent large } \\
\text { flow events }\end{array}$ & $\begin{array}{l}\text { 5-y prolonged } \\
\text { drought }\end{array}$ & $\begin{array}{l}\text { Bêche et } \\
\text { al. (2009) }\end{array}$ \\
\hline & $\begin{array}{l}\text { MedBasin } \\
\text { (South- } \\
\text { eastern } \\
\text { France) } \\
\end{array}$ & $\begin{array}{l}2051- \\
2080 \mathrm{~s}\end{array}$ & Fishes & $\begin{array}{l}\text { Richness in future decades } \\
\text { will increase and composition } \\
\text { will change considerably }\end{array}$ & $\begin{array}{l}\text { Warming and } \\
\text { change in } \\
\text { precipitation } \\
\text { regime }\end{array}$ & $\begin{array}{l}\text { Buisson } \\
\text { et al. } \\
(2008 \text {, } \\
2010) \\
\end{array}$ \\
\hline & $\begin{array}{l}\text { MedBasin } \\
\text { (South- } \\
\text { eastern } \\
\text { France) }\end{array}$ & $\begin{array}{l}2051- \\
2080 \mathrm{~s}\end{array}$ & Fishes & $\begin{array}{l}\text { Communities in future decades } \\
\text { will be more homogenous } \\
\text { downstream and more diverse } \\
\text { upstream. Species and traits } \\
\text { diversity will increase } \\
\text { upstream and composition will } \\
\text { change }\end{array}$ & $\begin{array}{l}\text { Warming and } \\
\text { change in } \\
\text { precipitation } \\
\text { regime }\end{array}$ & $\begin{array}{l}\text { Buisson } \\
\& \\
\text { Grenouill } \\
\text { et (2009) }\end{array}$ \\
\hline & $\begin{array}{l}\text { MedBasin } \\
\text { (Southern } \\
\text { Portugal) }\end{array}$ & $\begin{array}{l}1993- \\
2008\end{array}$ & $\begin{array}{l}\text { Macroinvertebr } \\
\text { ates }\end{array}$ & $\begin{array}{l}\text { Richness and evenness of } \\
\text { assemblages changed at } \\
\text { disturbed sites. Changes in } \\
\text { composition during extreme } \\
\text { events ( low precipitation } \\
\text { and/or temperature), with shift } \\
\text { in equity occurred before } \\
\text { elimination }\end{array}$ & $\begin{array}{l}\text { Climate } \\
\text { change: } 1{ }^{\circ} \mathrm{C} \\
\text { temperature } \\
\text { increase and } \\
1.5 \mathrm{~mm} / \mathrm{d} \\
\text { precipitation } \\
\text { decrease, and } \\
\text { extreme } \\
\text { events }\end{array}$ & $\begin{array}{l}\text { Feio et } \\
\text { al. }(2010)\end{array}$ \\
\hline & $\begin{array}{l}\text { MedBasin } \\
\text { (Southern } \\
\text { Portugal) }\end{array}$ & $\begin{array}{l}1991- \\
1998\end{array}$ & Fishes & $\begin{array}{l}\text { Species affected differently by } \\
\text { droughts and floods: some } \\
\text { declined or increased after dry } \\
\text { years while others declined } \\
\text { after rainy springs. Species } \\
\text { recovered quickly but might } \\
\text { depend of intensity and } \\
\text { duration of droughts and } \\
\text { floods }\end{array}$ & $\begin{array}{l}\text { Droughts and } \\
\text { floods }\end{array}$ & $\begin{array}{l}\text { Magalhã } \\
\text { es et al. } \\
(2007)\end{array}$ \\
\hline & $\begin{array}{l}\text { California } \\
\text { (Northern) }\end{array}$ & $\begin{array}{l}1984- \\
2003\end{array}$ & $\begin{array}{l}\text { Macroinvertebr } \\
\text { ates }\end{array}$ & $\begin{array}{l}\text { Indexes of biotic integrity } \\
\text { (IBI) changed across time; } \\
\text { several IBI metrics were } \\
\text { related to the El Nino Southern } \\
\text { Oscillation Index }\end{array}$ & $\begin{array}{l}\text { Climate } \\
\text { variability }\end{array}$ & $\begin{array}{l}\text { Mazor et } \\
\text { al. (2009) }\end{array}$ \\
\hline & $\begin{array}{l}\text { MedBasin } \\
\text { (Southern } \\
\text { Portugal) }\end{array}$ & $\begin{array}{l}\text { Summer } \\
2005\end{array}$ & Fishes & $\begin{array}{l}\text { Assemblages shaped by } \\
\text { drought refuges } \\
\text { characteristics: richness was } \\
\text { lower at smaller pools while } \\
\text { abundance was higher, and } \\
\text { cooler pools (shaded) had } \\
\text { highest richness }\end{array}$ & $\begin{array}{l}\text { Reduced } \\
\text { water flow, } \\
\text { drought }\end{array}$ & $\begin{array}{l}\text { Pires et } \\
\text { al. }(2010)\end{array}$ \\
\hline & $\begin{array}{l}\text { MedBasin } \\
\text { (North- } \\
\text { eastern } \\
\text { Spain) }\end{array}$ & $\begin{array}{l}1992- \\
1998\end{array}$ & $\begin{array}{l}\text { Salmo trutta } \\
\text { (fish) }\end{array}$ & $\begin{array}{l}\text { Survival of the youngest } \\
\text { depended of the low flows } \\
\text { during summer droughts }\end{array}$ & $\begin{array}{l}\text { Flow regime } \\
\text { variability, } \\
\text { droughts }\end{array}$ & $\begin{array}{l}\text { Nicola et } \\
\text { al. (2009) }\end{array}$ \\
\hline Life-history & $\begin{array}{l}\text { California } \\
\text { (Northern) }\end{array}$ & $\begin{array}{l}1984- \\
2003\end{array}$ & $\begin{array}{l}\text { Benthic } \\
\text { macroinvertebr } \\
\text { ates }\end{array}$ & $\begin{array}{l}\text { The longer-lived, larger } \\
\text { organisms were less abundant } \\
\text { in years with extreme climate } \\
\text { conditions; however common } \\
\text { indices and metrics used in } \\
\text { biological monitoring were not } \\
\text { influenced by climate } \\
\text { extremes }\end{array}$ & $\begin{array}{l}\text { Climate } \\
\text { (temperature } \\
\text { and } \\
\text { precipitation } \\
\text { extremes) }\end{array}$ & $\begin{array}{l}\text { Lawrenc } \\
\text { e et al. } \\
(2010)\end{array}$ \\
\hline
\end{tabular}




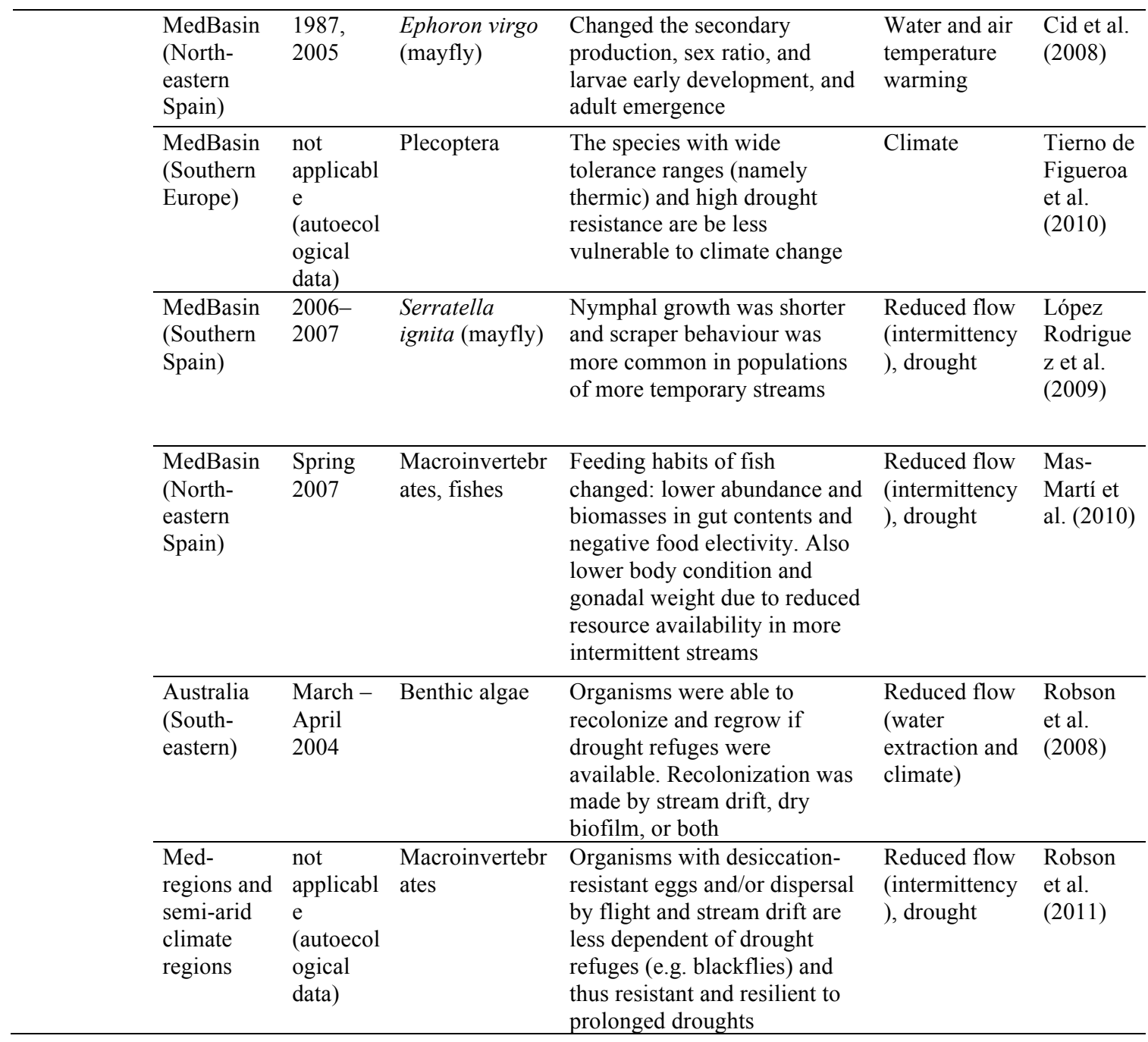


Table 2 Conservation status of freshwater taxa in med-regions based on studies that

conducted biodiversity surveys, including a description of the decline and suggested causes.

\section{MedBasin refers to Mediterranean Basin region.}

\begin{tabular}{|c|c|c|c|c|c|}
\hline Med-region & $\begin{array}{c}\text { Primary Legal } \\
\text { Tools for } \\
\text { Protection (date } \\
\text { of first } \\
\text { implementation) } \\
\end{array}$ & Taxa & Description of Decline & Correlated drivers & Source \\
\hline \multirow[t]{3}{*}{ California } & \multirow{3}{*}{$\begin{array}{l}\text { Clean Water Act } \\
(1972), \\
\text { Endangered } \\
\text { Species Act } \\
(1972), \\
\text { National } \\
\text { Environmental } \\
\text { Policy Act } \\
\text { (1969), } \\
\text { Wild and Scenic } \\
\text { Rivers Act } \\
\text { (1968) }\end{array}$} & Fish & $\begin{array}{l}63 \% \text { of native taxa } \\
\text { extinct or in danger of } \\
\text { extinction }\end{array}$ & $\begin{array}{l}\text { Hydrologic alteration, } \\
\text { land-use, drought }\end{array}$ & Moyle (1995) \\
\hline & & $\begin{array}{l}\text { Amphibia } \\
\text { ns and } \\
\text { reptiles }\end{array}$ & $\begin{array}{l}\text { Of } 20 \text { native aquatic } \\
\text { taxa examined, } 13 \\
\text { were endangered }\end{array}$ & $\begin{array}{l}\text { Hydrologic alteration } \\
\text { and landuse }\end{array}$ & $\begin{array}{l}\text { Jennings \& Hayes } \\
\text { (1994) }\end{array}$ \\
\hline & & $\begin{array}{l}\text { Amphibia } \\
\text { ns }\end{array}$ & $\begin{array}{l}\text { The endemic mountain } \\
\text { yellow-legged frog is } \\
\text { absent from } 50 \% \text { of its } \\
\text { historic range }\end{array}$ & $\begin{array}{l}\text { Introduction of non } \\
\text { native fish }\end{array}$ & $\begin{array}{l}\text { Knapp \& } \\
\text { Matthews (2000) }\end{array}$ \\
\hline \multirow[t]{4}{*}{ MedBasin } & \multirow[t]{4}{*}{$\begin{array}{l}\text { Water } \\
\text { Framework } \\
\text { Directive (2000) }\end{array}$} & Fish & $\begin{array}{l}78 \% \text { of native species } \\
\text { in a south-eastern } \\
\text { Pyrenees watershed } \\
\text { showed decline }\end{array}$ & $\begin{array}{l}\text { Pollution, habitat } \\
\text { modification }\end{array}$ & $\begin{array}{l}\text { Aparicio et al. } \\
(2000)\end{array}$ \\
\hline & & Fish & $\begin{array}{l}\text { Of } 11 \text { native taxa } \\
\text { examined, } 4 \text { were } \\
\text { endangered and } 3 \text { were } \\
\text { nearly extinct }\end{array}$ & $\begin{array}{l}\text { Introduction of } \\
\text { nonnative species }\end{array}$ & Bianco (1995) \\
\hline & & Fish & $\begin{array}{l}64 \% \text { of native species } \\
\text { in the Guadiana basin } \\
\text { are threatened }\end{array}$ & $\begin{array}{l}\text { Habitat degradation } \\
\text { and invasive species }\end{array}$ & $\begin{array}{l}\text { Hermoso et al. } \\
\text { (2011) }\end{array}$ \\
\hline & & Fish & $\begin{array}{l}56 \% \text { of endemic } \\
\text { freshwater fish species } \\
\text { threatened and } 18 \% \\
\text { endangered }\end{array}$ & $\begin{array}{l}\text { Pollution, water } \\
\text { extraction, restricted } \\
\text { range, limited } \\
\text { dispersal, drought, } \\
\text { invasive species, dam } \\
\text { construction }\end{array}$ & $\begin{array}{l}\text { Smith \& Darwall } \\
\text { (2006) }\end{array}$ \\
\hline Australia & $\begin{array}{l}\text { Australian Water } \\
\text { Act (2007), } \\
\text { Convention on } \\
\text { Biological } \\
\text { Diversity (1993), } \\
\text { Ramsar } \\
\text { Convention on } \\
\text { Wetlands (1971) } \\
\end{array}$ & Fish & $\begin{array}{l}3 \text { of } 10 \text { species in } \\
\text { south-west Australia } \\
\text { are listed as rare or } \\
\text { critically endangered }\end{array}$ & $\begin{array}{l}\text { River regulation, loss } \\
\text { of riparian vegetation, } \\
\text { salinization and } \\
\text { sedimentation, } \\
\text { eutrophication, and } \\
\text { introduction of exotic } \\
\text { animals and plants }\end{array}$ & $\begin{array}{l}\text { Lymbery et al. } \\
(2010)\end{array}$ \\
\hline \multirow[t]{2}{*}{ Chile } & \multirow[t]{2}{*}{$\begin{array}{l}\text { Convention on } \\
\text { Biological } \\
\text { Diversity (1993) }\end{array}$} & Fish & $\begin{array}{l}40 \% \text { of } 105 \text { streams } \\
\text { sampled had no natives }\end{array}$ & $\begin{array}{l}\text { Introduction of exotic } \\
\text { species }\end{array}$ & Soto et al. (2006) \\
\hline & & Fish & $\begin{array}{l}81 \% \text { of species are } \\
\text { endemic, } 40 \% \text { are } \\
\text { endangered }\end{array}$ & $\begin{array}{l}\text { Introduction of exotic } \\
\text { species }\end{array}$ & Habit et al. (2006) \\
\hline \multirow[t]{2}{*}{$\begin{array}{l}\text { South } \\
\text { Africa }\end{array}$} & \multirow[t]{2}{*}{$\begin{array}{l}\text { IUCN Red List } \\
\text { (1963) }\end{array}$} & Fish & $\begin{array}{l}47 \% \text { of endemic } \\
\text { species are threatened }\end{array}$ & Anthropogenic impacts & $\begin{array}{l}\text { Skelton et al. } \\
(1995)\end{array}$ \\
\hline & & Fish & $\begin{array}{l}15 \text { of } 36 \text { native species } \\
\text { examined are endemic, } \\
1 / 3 \text { of which are } \\
\text { threatened }\end{array}$ & $\begin{array}{l}\text { Farming and other } \\
\text { forms of land use, } \\
\text { exotics, mining, } \\
\text { industrial development, } \\
\text { human settlement, and } \\
\text { construction of dams }\end{array}$ & $\begin{array}{l}\text { Gaigher et al. } \\
\text { (1980) }\end{array}$ \\
\hline
\end{tabular}


Fig. 1 Number of publications in the Web of Science database since 1990 regarding climate change and biota (a) (search Topic=("climate change" OR "climatic change") AND Topic $=($ species OR biodiversity OR richness $))$, filtering by the ones mentioning fresh waters (b) (additional search Topic $=($ freshwater* OR fresh water* OR stream* OR lake* $)$, or filtering streams only (c) (additional search Topic $=($ stream* OR river*), and among these filtered by climatic regions (additional search Topic $=($ tropical $)$ or Topic $=($ desert $)$ or Topic $=($ temperate $)$ or Topic $=($ mediterr* OR “semi-arid” $))$.

Fig. 2 Possible responses of organisms to the ongoing climate change in freshwater communities of med-streams. Responses will depend in the processes involved, which act at ecological and evolutionary times, and thus the responses might be acting simultaneously but at distinct time and space scales. 
Fig. 1
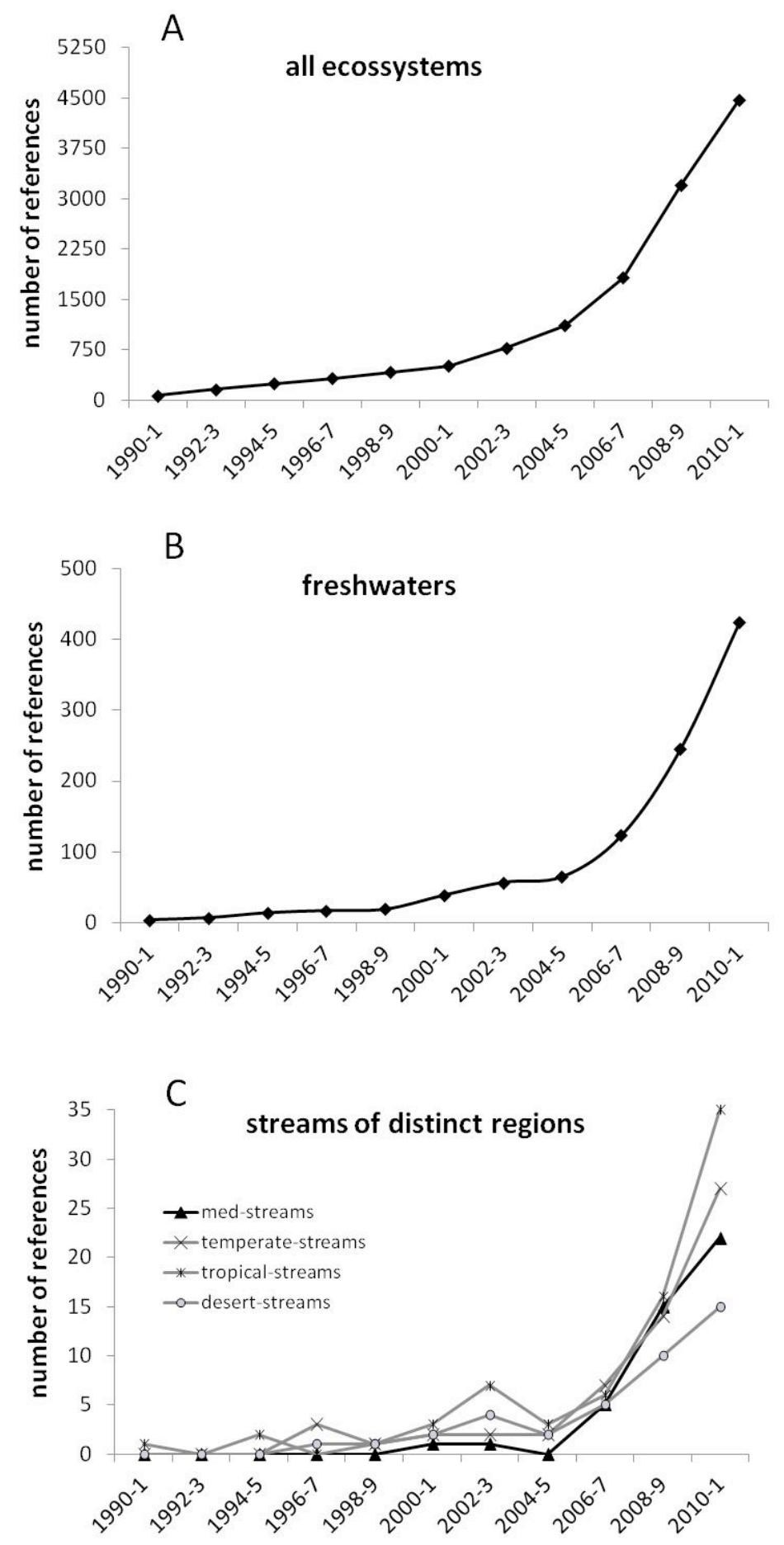
Fig. 2
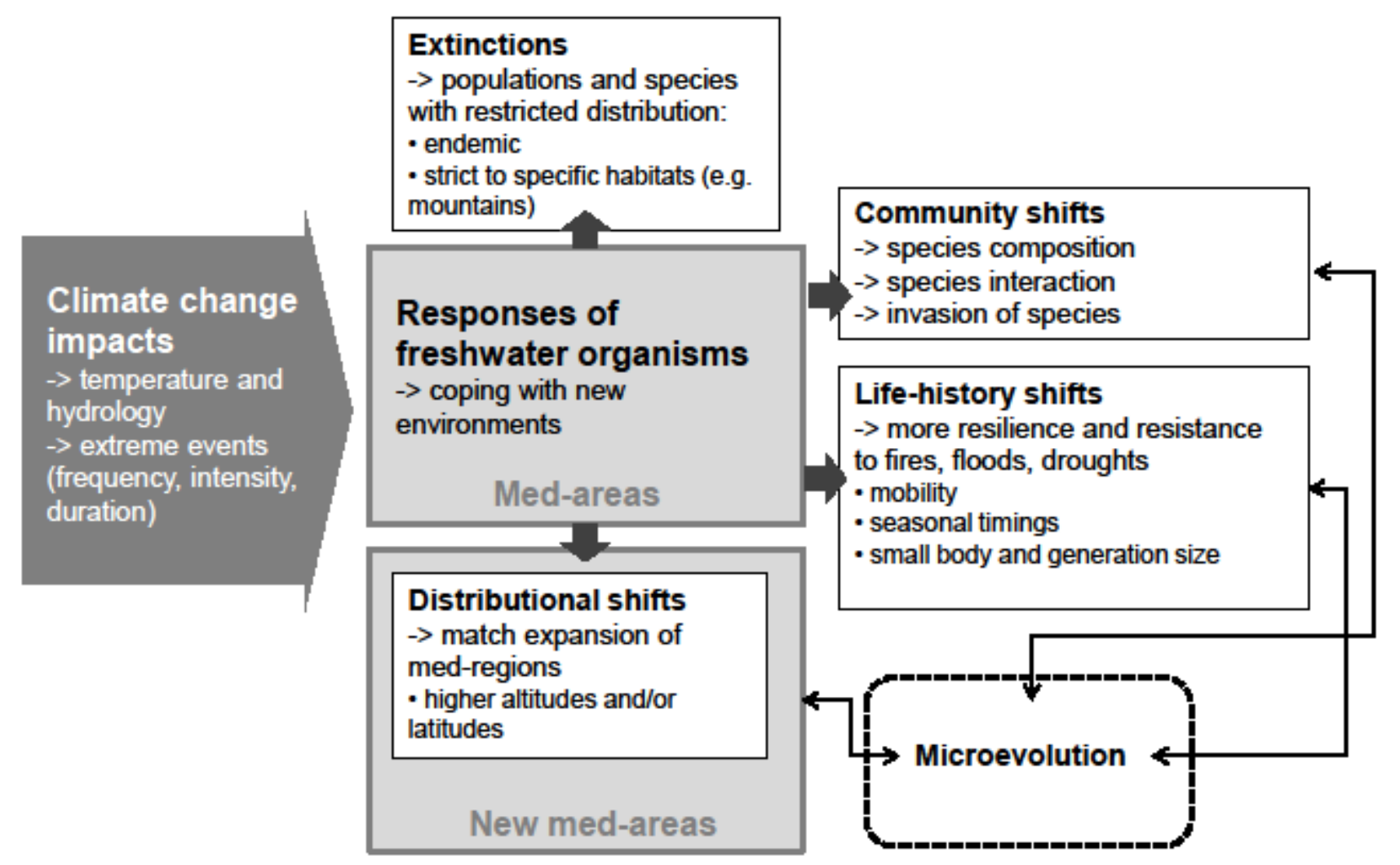